\title{
Early modern Dalmatian landscape and demographic changes in the multiple borderland area: cartographic vs. statistical data
} Ranonovovjekovne okolišne i demografske promjene na
dalmatinskom višestrukom pograničju:
usporedba kartografskih i statističkih podataka

This paper shows interdisciplinary insight into economy-driven early modern environmental change, using the example of the privately financed venture of marshland reclamation on Count Borelli's Vrana Estate. The research goal was to compare cartographic and demographic statistical sources to see how such an improvement was represented in correlated data, and if certain quantitative features of ecological, economic, and demographic development could be accurately measured. The focus was on the direct relationship between the enlargement of arable fields by drainage and the gradual overall advancement of the area. Quantitative analysis failed to offer reliable results, primarily due to inconsistent cartometric and content comparability of available sources. Qualitative analysis revealed that marshland drainage and soil improvement of potentially very fertile land, along with the colonisation of new inhabitants as agrarian land users and taxpayers, provided a moderate opportunity for demographic increase in rather depressive circumstances. Due to Venetian-Ottoman wars, the once agriculturally prosperous area of Vrana was rendered into an ecologically-unstable, economically-devastated, politically and militarily-pressured, socially-wrecked, and demographically half-deserted landscape.

Key words: Borelli of Vrana (family), the feudal Vrana Estate, maps, land reclamation, demography, migrations, economy, Ravni kotari, $17^{\text {th }}-18^{\text {th }}$ century
Članak pruža interdisciplinarni uvid u svjesno inicirane ekonomske i okolišne promjene na primjeru ranonovovjekovnoga pothvata privatnoga projekta isušivanja močvara na feudalnom posjedu Borelli u Vrani. Cilj usporedbe kartografskih i demografskih statističkih podataka bio je pronaći naznake promjena koje je okolišni zahvat izazvao te kvantificirati ekonomski, ekološki i demografski napredak u promatranim izvorima. Fokus je stavljen na pronalaženje konkretne veze između proširivanja obradivih površina isušivanjem i postupnoga sveukupnog razvitka Ravnih kotara. Pokušaj kvantitativne analize kartografskih izvora nije ponudio mjerljive rezultate, prije svega zbog kartometrijske i sadržajne neusporedivosti dostupnih izvora. Kvalitativna je analiza pokazala da je isušivanje močvara te bonifikacija potencijalno vrlo plodna tla, uz naseljavanje novih stočarskih poreznih obveznika u nepovoljnim okolnostima, predstavljalo tek jednu od pretpostavaka za demografski rast. S druge su strane mletačko-osmansko ratovanje i političko-vojni pritisci na duže vrijeme pretvorili Vranu, nekada plodnu žitnicu, u ekološki nestabilan, ekonomski i socijalno devastiran te demografski opustošen kraj.

Ključne riječi: Borelli Vranski (obitelj), feudalni posjed Vrana, karte, melioracija, demografija, migracije, ekonomija, Ravni kotari, 17. - 18. stoljeće 
HRVATSKI

GEOGRAFSKI

GLASNIK

82/1,35-58 (2020.)

\section{Introduction}

This research is focused primarily on early modern local land reclamation and soil improvement (bonification) actions, in the scope of private projects and deliberate landscape change processes in northern Dalmatia, and their impacts on the economic, demographic, and overall change of the feudal Vrana Estate. As an eastern Adriatic multiple borderland area, the Vrana Estate was located in a conflict contact zone of different states, economic systems, cultures, and religions for centuries which has certainly marked its evolution. Maritime and continental economic tradition and Christianity and Islam, were just few of these development lines. At the same time, it was an area of constant, mostly fortuitous and unrecorded migrations, circulation and exchange of people, goods and ideas, and in that respect it can be considered as a territory of co-existence of different approaches and policies in ecology, economy, medicinal practices, and land use. After various peace treaties were signed, new inhabitants, mostly Orthodox Vlach-Morlach shepherds, who were of a different ethnicity in comparison to pre-Ottoman Vlachs who once inhabited the area, populated the villages deserted by their former Catholic population (Fürst-Bjeliš et al., 2003). Their semi-nomadic way of life considerably contributed to the spread of the extensive and low-maintenance economy of pastoral herding, setting a new tradition.

The paper aims to reveal how such environmental changes have been recorded in cartographic documents of large and medium scale (maps, plans, sketches), during an approximate 200-year period $\left(17^{\text {th }}\right.$ and $18^{\text {th }}$ centuries). Additionally, the way this can be correlated with numerical demographic, economic and statistical, found in Church registries (Matriculae), estate family records (Alberi Genealogici), and cadastral data (both graphic and numerical) is explored. An additional goal was to determine, based on the aforementioned comparison, how landscape change influenced further economic, demographic, and environmental expansion. The research is theoretically and conceptually positioned within the framework of comparative border society research, which have only been elaborated in national historical literature (Fürst-Bjeliš et

\section{Uvod}

Ovo istraživanje usmjereno je u prvom redu na projekte lokalne ranonovovjekovne melioracije i isušivanja plodnoga tla (bonifikacija) na vranskom feudalnom posjedu u Sjevernoj Dalmaciji, koji su u okviru privatno financirana projekta ciljano provođeni s namjerom podizanja ekonomske, ali i ukupne produktivnosti, te poticanja demografskoga rasta. Kao istočnojadransko višegraničje, vranski je posjed desetljećima predstavljao konfliktno stjecište različitih država, gospodarskih, kulturnih i vjerskih sustava, koji su bitno obilježili njegov razvitak. Kopnena ili pomorska gospodarska tradicija s jedne strane, odnosno kršćanstvo i islam s druge, bili su samo neki od primjera takvih suprotstavljenih višestrukosti. Istodobno je vransko dobro bilo prostor spontanih i slabo dokumentiranih migracija, kruženja i izmjene ljudi, roba i ideja te ujedno prostor sustjecanja raznolikih pristupa i ekoloških, ekonomskih i liječničkih praksi, kao i politika korištenja zemljišta. Novo su stanovništvo pretežito činili vlaško-morlački stočari, koji su pripadali drugačijem etničkom korpusu, posebno u odnosu na predosmansko razdoblje. Napuštena sela nakon mirovnih sporazuma umjesto katoličkoga stanovništva naseljavaju većinom pravoslavni Morlaci (Fürst-Bjeliš i dr., 2003). Njihov novouvedeni polunomadski način gospodarenja predstavlja doprinos širenju niskozahtjevne ekstenzivne pašnjačke stočarske ekonomije, koja je postavila temelje razvoju novih tradicija.

U članku se propituje mogu li se ekološke promjene koje su bilježili kartografski izvori krupnoga i srednjega mjerila (karte, planovi i nacrti) tijekom gotovo dva stoljeća (17. - 18.) usporediti s demografskim i ekonomskim statističkim (numeričkim) podatcima. Oni su zabilježeni u matičnim knjigama (Matriculae), obiteljskim fondovima feudalnih obitelji (Alberi Genealogici) i u katastarskim izvorima (bilo grafičkima, bilo numeričkima). Istraživački je cilj bio na temelju komparativne analize propitati kako je promjena okoliša utjecala na prostorno širenje te ekonomski i demografski rast. Teorijski se rad svojim konceptom naslanja na komparativne studije pograničnih društava, koje su tek dijelom istražene u domaćoj literaturi (Fürst-Bjeliš i dr., 2003; Mayhew, 2008; Petrić, 2012; Roksandić, 2018), 
al., 2003; Mayhew, 2008; Petrić, 2012; Roksandić, 2018) and usually analyse only few typical micro-historical features of this sort of multi-layered and complex landscape. Moreover, environmental history ${ }^{1}$ and historical demography discourses, namely in relation to border changes (Fuerst-Bjeliš and Zupanc, 2007; Rimac and Mladineo, 2009), offer additional perspectives. Detection, evaluation, comparison, and scientific manipulation of sources opened a parallel line of research, making this a challenging and somewhat experimental usage of computer programs and/or approaches to the selected array of archival data. From a methodological perspective, the research follows the principles of an interdisciplinary approach, combining elements of historical cartography, demography, and economics, in order to discover a hidden story from Mediterranean (karst) environmental history, using elements of simultaneously collected statistical data. Although it is based on qualitative comparative and retrospective analysis of demographic and economic archival sources, this research also explores existing secondary literature that deals with analyses of similar ecological phenomena ${ }^{2}$. Published and often critically commented archival sources were also of significant value (Rimac and Mladineo, 2009). Earlier qualitative research of features like political or administrative regulations or land management ${ }^{3}$ was used to enhance further scientific endeavours, aimed at exploring the possibilities of early modern quantitative trans-media data comparison of cartography and statistics. The goal was to determine

1 Primarily it considered environmental history material as documentation of physical changes, as opposed to intellectual environmental history or perception of prior landscape or environmental history, i.e. legal or administrative regulations for land use and management (McNeill, 2003).

2 The example is the research of the medieval marsh reclamation near the Italian city Ravenna (in the Po River lowlands), which was a helpful eco-historical source for comparing similar practices around the Adriatic basin. Moreover, it was an example of use of literary records in historical landscape reconstruction (Squatriti, 1992). The comparison of cartographic and statistical (numerical) data was rare in previous research in this field, especially from the early modern era, but along with the expertise in similar areas it certainly enabled new lines of demographic-economic investigation, and better understanding of the overall environmental change, and changes in demographics and the cultural landscape (Fürst-Bjeliš, 2003; Fuerst-Bjeliš et al., 2011; Čuka et al., 2012; Blaće, 2019).

3 Qualitative research on some specific elements of Vrana Estate reclamations was conducted more extensively and published in: Mlinarić (2006); and Mlinarić and Župarić-Iljić (2017). zahvaćajući samo nekoliko tipičnih mikrohistorijskih fenomena tako složenoga, podvojenoga odnosno višeslojnoga pejzaža kao što je Vrana. Dodatna je istraživačka perspektiva pronađena u okvirima diskursa povijesti okoliša, ${ }^{1}$ ali i povijesne demografije, prije svega one vezane uz promjene granica (Fuerst-Bjeliš i Zupanc, 2007; Rimac i Mladineo, 2009). Istraživanje je uključilo utvrđivanje izvora, njihovo vrednovanje, usporedbu te znanstvenu obradu, kroz izazov propitivanja donekle eksperimentalnoga korištenja računalnih programa i pristupa odabranoj građi. Metodološki gledano, u istraživanju je korištena interdisciplinarna kombinacija principa povijesne kartografije, demografije, ekohistorije sredozemnoga krša, ali i onodobni statistički podatci. Iako temeljeno na kvalitativnoj usporedbi i retrospektivnoj analizi demografskih i ekonomskih povijesnih izvora, kompleksno je istraživanje obuhvatilo preispitivanje postojeće literature o sličnim ekološkim fenomenima. ${ }^{2} \mathrm{U}$ analizi su također važni i objavljeni arhivski izvori, često popraćeni kritičkim komentarima (Rimac i Mladineo, 2009). Nastojeći odgovoriti na izazove usporedbe ranonovovjekovnih raznorodnih izvora (kartografskih i statističkih), u radu su se koristila prethodna istraživanja kvalitativne naravi u područjima kao što su administrativne politike i regulative ili pak gospodarenje zemljom. ${ }^{3}$ Uspoređeni su modifikatori razvoja kao što su npr. kvantitativno dokumentirana melioracija tla te s njome vezani predmoderni demografski trendovi na feudalnom posjedu, uključujući i

1 Prvenstveno se misli na okolišnu povijest, koja je dokumentirala fizičke promjene, nasuprot intelektualnoj okolišnoj povijesti, odnosno percipiranju okoliša u prošlosti, konkretnije pravnom i administrativnom reguliranju korištenja i upravljanja zemljom (McNeill, 2003).

2 Primjer je istraživanje melioracija srednjovjekovnih močvara pokraj talijanske Ravene (Padske nizine), koji je koristan ekohistorijski izvor za usporedbu sličnih praksi u jadranskom bazenu. Ujedno je to primjer korištenja književnih izvora u rekonstrukciji povijesnoga okoliša (Squatriti, 1992). Premda je usporedba karata i brojčanih podataka u dosadašnjim istraživanjima vranskoga prostora bila vrlo rijetka, posebno za rani novi vijek, ona je u usporedbi s istraživanjima sličnih ili susjednih prostora omogućila postavljanje novih pitanja na relaciji demografija-ekonomija, ali i posljedičnu analizu promjena okoliša, stanovništva i kulturnoga pejzaža (FürstBjeliš, 2003; Fuerst-Bjeliš et al., 2011; Čuka et al., 2012; Blaće, 2019).

3 Rezultati kvalitativnoga istraživanja izabranih čimbenika melioracijskih procesa na vranskom posjedu detaljnije su obrazloženi i objavljeni u: Mlinarić (2006); Mlinarić i Župarić-Iljić (2017).
D. Mlinarić I. Kljajić

Early modern

Dalmatian

landscape and

demographic

changes in the

multiple borderland

area: cartographic

vs. statistical data

Ranonovovjekovne okolišne i

demografske

promjene na

dalmatinskom

višestrukom pograničju: usporedba

kartografskih i

statističkih podataka 
HRVATSKI

GEOGRAFSKI

GLASNIK

82/1,35-58 (2020.) how development accelerators such as land reclamation and corresponding proto-modern demographic trends, including migrations (i.e. spatial redistribution of existing inhabitants ${ }^{4}$ ), on the Estate were recorded in a quantitative manner. However, the quantitative analyses of known and preserved maps did not reveal any usable or comparable results, due to the various agrarian or legal systems and policies intertwined throughout, but also due to incomparable/inconsistent set of maps of different scales (Fürst-Bjeliš et al., 2003). Therefore, this research was redirected to comparative and descriptive analysis, based on lapidary sources.

\section{Early modern Vrana Estate demography, according to various records (cartographic vs. statistical)}

As the historical and geo-strategical context of Venetian-Ottoman wars is of significant importance for contextualisation of reclamation actions performed on Vrana Estate, a short insight into the land improving drainage project on the Estate will be provided. These private enterprises were funded and carried out by Count Francesco Borelli, a European intellectual who shared the inventive and sometimes experimental ideas of the Physiocratic movement for land-use improvement and productivity increase, and applied them on his holdings. Similar ideas gradually spread among the Mediterranean elite, also including its eastern Adriatic members ${ }^{5}$. After the Venetian (re)conquest of Zadar's hinterland (in 1684) it was reorganised within Venetian Dalmatia, including the territory of Acquisto Nuovo in 1699 and Acquisto Nuovissimo

\footnotetext{
4 Which occurred prior the statistical period of documentation of migrations or modern and systematic data recording. Furthermore, some of these movements had elements of ecological migrations, which would be among the most important kind of migrations worldwide in the decades to come.

5 Among the ideals of political economists, who believed in land as a source of prosperity, Count Borelli attempted to overcome the interference of government policy with the natural economic law of the landowner in Vrana (Božić-Bužančić, 1995). In this case, the landscape utilisation coincided with lack of political support and sometimes unsuccessful and conflicting production-consumption relations, which consequently led to the financial stagnation of the Borelli family (HR-DAZD-348, Borelli Estate statistics, 1752-1798, vol. 60 , no. I/IV).
}

migracije kao prostornu redistribuciju postojećega stanovništva. ${ }^{4}$ Pokazalo se da korištenje kvantitativnih analitičkih metoda na primjerima poznatih i sačuvanih karata ne može ponuditi iskoristive usporedbene rezultate, dok u drugim slučajevima brojčane razlike mogu proizaći iz različitih agrarnih ili pravnih sustava i politika koje se isprepleću u vrlo kratkom vremenskom odsječku (Fürst-Bjeliš i dr., 2003). Razlog tomu moguće je pronaći i u teško usporedivim kartama različitih mjerila. Zbog toga je istraživanje preusmjereno prema komparativnoj te deskriptivnoj analizi, premda su izvori za nju bili lapidarni.

\section{Demografija ranonovovjekovnoga posjeda Vrana u različitim vrstama izvora (kartografski nasuprot statističkima)}

S obzirom na to da je povijesni i geostrateški kontekst mletačko-osmanskoga ratovanja u znatnoj mjeri odredio tijek melioracijskih radova na feudalnom posjedu, ukratko su predstavljeni bonifikacijski radovi na isušivanju Vrane. Spomenuti je privatni pothvat financirao i proveo grof Francesco Borelli, kao europski intelektualac koji je dijelio inventivne i katkad eksperimentalne ideje fiziokratskoga pokreta i na svom posjedu prakticirao inovativno iskorištavanje zemljišta $\mathrm{s}$ ciljem porasta produktivnosti. Slične su se ideje širile među elitom na Sredozemlju, ali i na Jadranu. ${ }^{5}$ Nakon ponovnoga mletačkog zauzimanja zadarskoga zaleđa (1684.) ono je organizirano u okvirima mletačke Dalmacije, uključujući prostor Nove stečevine (Acquisto Nuovo), pripojen 1699. godine i Najnovije stečevine (Acquisto Nuovissi-

\footnotetext{
4 Radi se o pretpopisnom statističkom razdoblju, prije sustavne registracije migranata suvremenim unificiranim načinom bilježenja podataka. K tomu, dio je tih kretanja imao obilježja ekoloških migracija, koje će biti među najizrazitijim oblicima svjetskih migracija u desetljećima koja slijede.

5 Među idejama političkih ekonomista, koji su zemlju držali temeljem prosperiteta, grof Borelli izdvajao se nastojanjem da prevlada upletanje državnih politika i administracije u svoje ekonomsko i prirodno pravo vlasništva nad Vranom (Božić-Bužančić, 1995). U njegovu se slučaju uređivanje okoliša podudaralo s izostankom političke potpore i s kadgod neuspješnim pa i konfliktnim odnosom proizvodnje potrošnje, što je dovelo do financijske stagnacije obitelii Borelli (HRDAZD-348, Statistika feudalnog posjeda Borelli 1752.-1798., sv. 60 br. I/IV).
} 
(in 1718) ${ }^{6}$. The micro-locality of the feudal Vrana Estate $^{7}$, composed of 9 villages ${ }^{8}$, was given as an investiture or laudemio (feudal property tenured according to hereditary law) to the noble family Borelli from Bologna in 1752 (Peričić, 1971, 393). The Borelli family undertook the herculean task of marshland melioration and land reclamation in order to improve the economy in the area (which was backward by the standards of the time), as Vrana had been governed by various church orders until that point and was ripe for improvement. This project shaped the area, which had been previously devastated and abandoned. It is indicative that documented data from the $16^{\text {th }}$ and $17^{\text {th }}$ centuries show a number of Ottoman dignitaries or state officials who reinforced and improved former Roman water-management architecture and in that sense prolonged the protection of water channels on the Estate. In doing so they improved agriculture and introduced additional economic branches in order to diversify and enhance overall development ${ }^{9}$. The turning point occurred during the destructive wars against the Ottoman Empire ${ }^{10}$ in the second half of the $17^{\text {th }}$ century. Demographic devastation ${ }^{11}$ and

6 First term denotes the Venetian territories acquired after the Great Turkish War (1683-1699) according to the Treaty of Srijemski Karlovci (Karlowitz), and second denotes the territories gained after the Treaty of Požarevac (Passarowitz), which ended the 1716-1718 Austro-Turkish War.

7 The estate was previously an Ottoman mezra of the Durakbegović family, ancestors of Halil-beg Alagić (Hafizović, 2016, 16; Zahirović, 2017).

8 They cover the territory of the contemporary villages and cities Tinj, Banjevci, Vrana, Radošinovci, Turanj, Biograd na Moru, Sv. Filip i Jakov, Dobra Voda, Stankovci, Pakoštane, Betina, and Murter (Stanojević, 2004, 177).

9 Some examples can be found regarding the feudal holdings of the Durakbegović family in Vrana, the Sokolović family in Tinj, or the Mašković family in Vrana, who even exploited strategic communication crossroads and initiated construction of the residential complex (Maškovića han) in Vrana (Traljić, 1965, 213-218; Rimac and Mladineo, $2009,10)$. This monumental building was a public inn, but instead of being built by the whole family it was a public purpose endowment of a single, but extremely distinguished, member of the Mašković family. Jusuf-Pasha was an Ottoman admiral and Kapudan Pasha with a successful career, which ended suddenly in 1646 with his decapitation. This course of events terminated the construction of Vrana Inn (Han).

10 Which were usually followed by deliberate destructive actions of water poisoning, building destruction, or field burning, which all tended to prevent or at least limit (re)settlement of Ottoman subjects on deserted land (Traljić, 1965, 211-219).

11 Direct testimony of significant human and material costs of long-lasting Venetian-Ottoman wars, among others, can be found in some Ottoman censuses for the areas in question (Hafizović, 2016). mo), uključen 1718. godine. ${ }^{6}$ Mikrolokalitet vranskoga feudalnog imanja, ${ }^{7}$ sastavljenog od devet sela, ${ }^{8}$ darovan je u obliku investiture kao laudemio (feudalni posjed zakupljen na ime nasljednoga prava) plemićkoj obitelji Borelli iz Bologne 1752. godine (Peričić, 1971, 393). Obitelj je pokrenula veliki projekt isušivanja močvara i melioracije tla s ciljem gospodarskoga unaprjeđenja prostora koji je u antici i u srednjem vijeku, dok su Vranom upravljali različiti crkveni redovi, bio plodna žitnica. Tim je projektom prostor, koji je prethodno bio devastiran i napušten, ponovno antropogeno oblikovan. U 16. i 17. stoljeću zabilježeno je da su i osmanski posjednici i državni činovnici nastojali ojačati i unaprijediti stare rimske vodne kanale i slične objekte te su kontinuirano štitili vodnu infrastrukturu na posjedu. Time su i oni nadograđivali agrarnu ekonomiju te uvodili dodatne djelatnosti ne bi li raznolikošću potakli ukupan razvitak. ${ }^{9}$ Prekretnicu su činili destruktivni protuosmanski ratovi ${ }^{10}$ tijekom druge polovice 17. stoljeća. Demografsko pustošenje ${ }^{11}$ koje je uslijedilo i posljedični gospodarski razvoj pratile su neprestana politička i vojna nesigurnost na pogra-

6 Prvi pojam označava mletački teritorij koji je osvojen nakon Velikog rata (1683. - 1699.), sukladno odredbama Karlovačkoga mira, a drugi teritorije stečene nakon Požarevačkoga mira, kojim je završen rat između 1716. i 1718. godine.

7 Posjed je prethodno, kao mezra, pripadao obitelji Durakbegović, predcima Halil-bega Alagića (Hafizović, 2016, 16; Zahirović, 2017)

8 Uključuje prostor današnjih sela i naselja Tinj, Banjevci, Vrana, Radošinovci, Turanj, Biograd na Moru, Sv. Filip i Jakov, Dobra Voda, Stankovci, Pakoštane, Betina i Murter (Stanojević, 2004, 177).

9 Primjer su feudalni posjedi Durakbegovića u Vrani, obitelji Sokolović u Tinju ili obitelji Mašković u Vrani. Posljednji su čak iskoristili stratešku komunikacijsku raskrsnicu koja je tuda prolazila te su započeli gradnju kompleksa (Maškovića han) u Vrani (Traljić, 1965, 213-218; Rimac and Mladineo, 2009, 10). Han je po svojoj temeljnoj funkciji bio odmorište javne namjene. Nije riječ o objektu koji je gradila cijela obitelj, nego o javnom objektu koji je dao sagraditi jedan - i to vrlo istaknut - pripadnik obitelji Mašković. Riječ je o Jusuf-paši, čija je strelovito uspješna karijera (bio je kapudan-paša, osmanlijski admiral) naprasno završila 1646. smaknućem, što je zaustavilo dovršetak hana u Vrani.

$10 \mathrm{U}$ okviru njih često se pribjegavalo ciljanom uništavanju kuća, trovanju vode, paljenju plodnih polja, sve u nastojanju da se spriječi ili bar kontrolira naseljavanje osmanskih podanika kao povratnika na napuštena selišta (Traljić, 1965, 211-219).

11 Izravna potvrda velikih ljudskih i materijalnih gubitaka dugotrajnih mletačko-osmanskih ratova može se, između ostaloga, pronaći i u određenim osmanskim popisima (defteri) za promatrano područje (Hafizović, 2016).
Early modern

Dalmatian

landscape and

demographic

changes in the

multiple borderland

area: cartographic

vs. statistical data

Ranonovovjekovne okolišne i

demografske

promjene na

dalmatinskom

višestrukom pograničju: usporedba

kartografskih i

statističkih podataka 
GEOGRAFSKI

GLASNIK

82/1,35-58 (2020.) corresponding economic development coincided with continuous political and military insecurity in the borderland $(s)^{12}$, proving that the geostrategic relevance of the Estate's location on the peripheries of neighbouring states was extremely important.

Apart from social reasons, these processes of conversion of the once prosperous fertile fields of Vrana into a marsh were in accordance with processes of natural environmental transformation following the Little Ice Age during the Middle Ages (Mlinarić, 2006, 47-52). Its significance lay in the fact that the climate throughout Europe turned cooler and wetter, whilst marshlands and swamps consequently grew in numbers and area, extending the effects of malaria and similar waterborne diseases (Racz, 2010, 21). This also resulted in loss of grain crops with numerous famines ${ }^{13}$ all around the Mediterranean, which consequently made Borelli's environmental and engineering land improving efforts in the following centuries more difficult (Petrić, 2012, 32).

\section{Methodological struggle: from qualitative to quantitative research and back}

In order to explore how Vrana's melioration project and correlated environmental and demographic changes were recorded in selected cartographic documents (of different provenance, technique, purpose, and content ${ }^{14}$ ) during a period of approximately 170

12 They existed on the Austrian and Venetian side (as krajine) and on the Ottoman side (as serhat). The tripartite borderland was populated by a specific section of society, highly defined by their liminal obligation of border defence (Mlinarić, 2006, 44). Even "family structure" or "structures of social communities" are perceived as phenomena of continuity, as well as of discontinuity within the unique frontier culture, composed of the dynamic relations of local identities (linguistic, ethnic, religious) and the broader (imperial) picture (Roksandić, 2018, 307-311).

13 Sources recorded ten enormously far-reaching famines from 1714 to 1794, followed by long-lasting starvation and food shortages (Mlinarić, 2006, 42).

14 In this particular case, the comparison is made using a map with a slight thematic inclination towards borders and political divisions, and another (early modern) topographic, more detailed map. While this particular Dutch cartographer made only one map originally, Venetian state offices issued another for administrative purposes. All these differences changed not just the purpose and aim of the map but also the sources used and geographical accuracy of the space visualisation, adding to the questionable reliability of archival sources (Mlinarić and Miletić Drder, 2017, 29-30). ničjima. ${ }^{12}$ One su još više, kao izrazito važnu, naglašavale ulogu geostrateškoga položaja posjeda na rubovima susjednih jakih država.

Uz društvene motive, spomenuti su procesi „odmočvarivanja” odnosno namjernih „zamočvarivanja" nekoć perspektivnih plodnih polja Vrane bili u suglasju s prirodnom preobrazbom okoliša, koje su u jugoistočnoj Europi pratile i srednjovjekovne epizode maloga ledenog doba (Mlinarić, 2006, 47-52). Važnost je takvih klimatskih poremećaja u činjenici da je cijela Europa bivala hladnija i vlažnija, pri čemu su močvare i blata bili brojni i široko rasprostranjeni, a s njima i širenje posljedica malaričnih i sličnih bolesti ljudi i životinja koje se mogu dovesti u vezu s vodenim površinama (Racz, 2010, 21). One su pak uzrokovale propast žitnih uroda s brojnim krizama gladi posvuda na Sredozemlju. ${ }^{13}$ Sve su te okolnosti prethodno djelovale na Borellijev okolišni inženjerski projekt, otežavajući mu bonifikaciju tla u idućim stoljećima (Petrić, 2012, 32).

\section{Metodološka preispitivanja: od kvaliłativne metode prema kvantitativnoj i natrag}

U nastojanju da se preispita korelacija melioracijskih projekata na Vrani, kao i pratećih okolišnih i demografskih promjena, te način na koji su one zabilježene u izabranoj kartografskoj građi (različite provenijencije, tehnika, namjena i sadržaja $)^{14}$

12 I s austrijske is mletačke strane prostor je bio organiziran u krajine, dok se s osmanske strane nalazio serhat. Takvo trodijelno višegraničje bilo je naseljeno posebnim pograničnim zajednicama, koje su bile obilježene graničnom obvezom sudjelovanja u obrani granica (Mlinarić, 2006, 44). Čak su i „strukture obitelji” odnosno cijelih društvenih zajednica doživljavane kao fenomen kontinuiteta, ali i diskontinuiteta prisutnih u specifičnoj kulturi pograničnih društava. Takva je kultura bila sastavljena od dinamičnih odnosa lokalnih identiteta (jezičnih, etničkih, konfesionalnih) i šire (imperijalne) slike (Roksandić, 2018, 307-311).

13 Između 1714. i 1794. godine izvori su zabilježili čak deset razdoblja intenzivne nestašice hrane s dalekosežnim posljedicama, među kojima su bile i dugotrajne faze gladi (Mlinarić, 2006, 42).

$14 \mathrm{U}$ konkretnom je slučaju uspoređena karta donekle tematskoga sadržaja (politička karta i karta granica) s drugom ranonovovjekovnom detaljnijom topografskom kartom. Prvu je izradio nizozemski kartograf, dok su drugu za administrativne potrebe priredili mletački državni službenici. Upravo su spomenute razlike dovele ne samo do razlikovanja namjene i cilja tih dviju karata već i do razlike u predlošcima kojima su se njihovi autori služili te geografske vjerodostojnosti svake od tih prostornih vizualizacija. Svi navedeni elementi dodatno svjedoče o upitnoj vjerodostojnosti karte kao pouzdanoga povijesnog izvora (Mlinarić i Miletić Drder, 2017, 29-30). 
Fig. 1 The Lake and swamps of Vrana on Janssonius' map from $1620 \mathrm{AD}$, in detail SI. 1. Vransko jezero i močvare na karti loannesa Janssoniusa iz oko 1620. godine, isječak Source / Izvor: NSK, ZN-Z-XVIIJAN-1620b

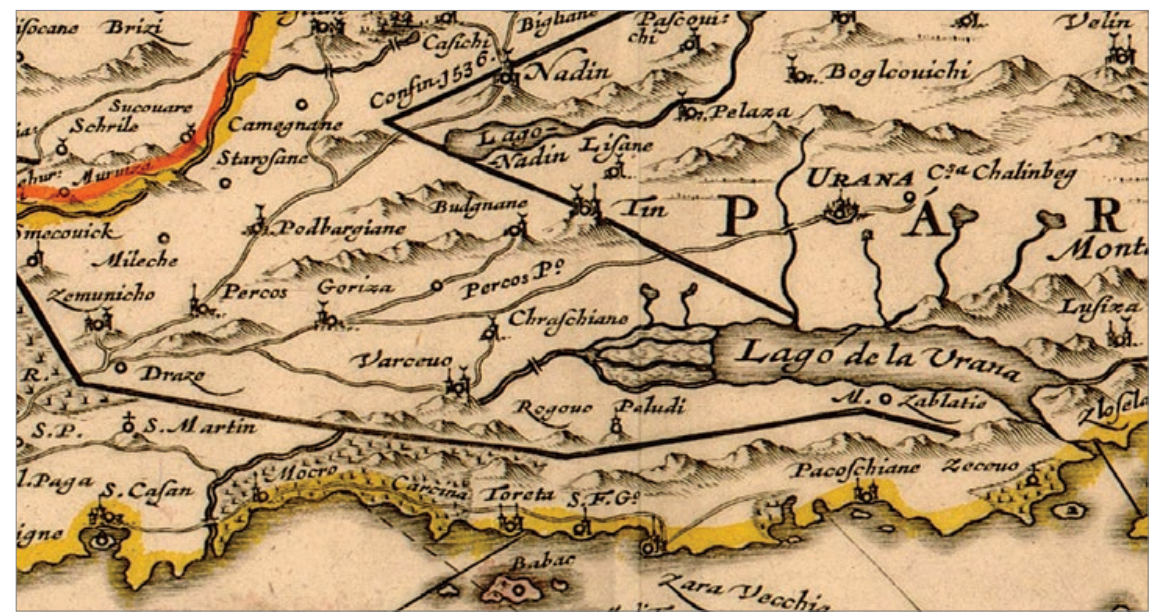

Fig. 2 The Lake and swamps of Vrana on Coronelli's map from 1688 , in detail

SI. 2. Vransko jezero i močvare na karti Vincenza Marije Coronellija iz 1688. godine isječak Source / Izvor: NSK, S-JZ-XVII-62

Fig. 3 The Lake and swamps of Vrana on Santini's map from 1780 , in detail

SI. 3. Vransko jezero i močvare na karti Paola Santinija iz 1780. godine, isječak Source / Izvor: NSK, S-JZ-XVIII-18
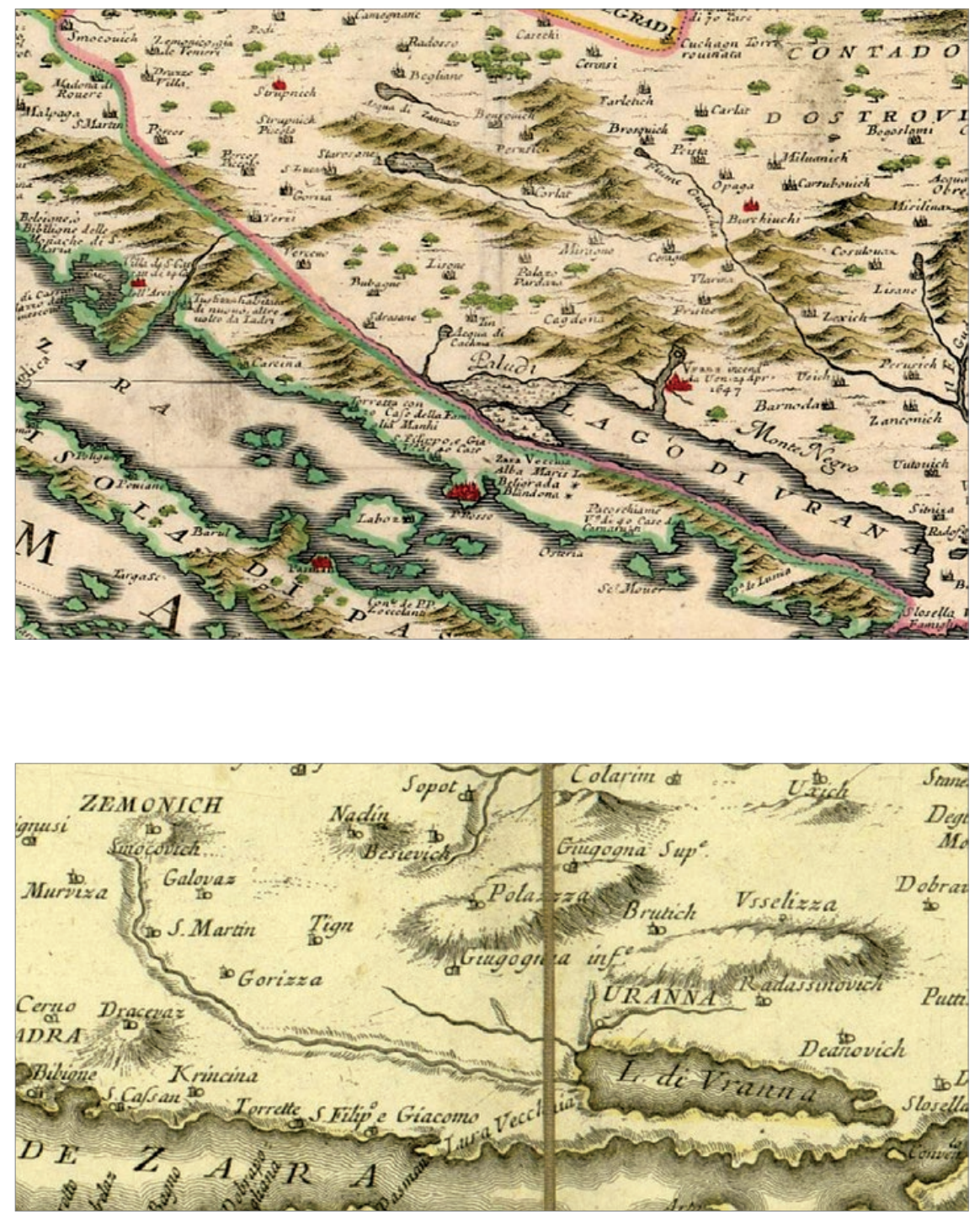

D. Mlinarić I. Kljajić

Early modern

Dalmatian

landscape and

demographic

changes in the

multiple borderland area: cartographic vs. statistical data

Ranonovovjekovne okolišne i demografske promjene na dalmatinskom višestrukom pograničju: usporedba

kartografskih i statističkih podataka 
HRVATSKI

GEOGRAFSKI

GLASNIK

82/1,35-58 (2020.)

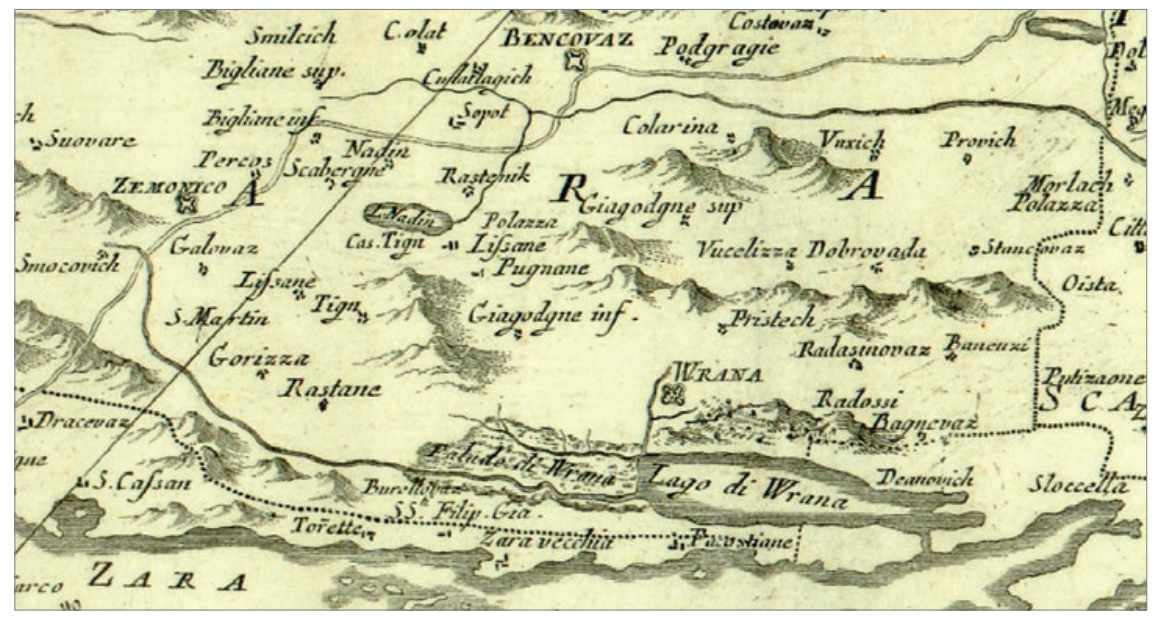

Fig. 4 The Lake and swamps of Vrana on the map of Francesco Melchiori, Frane Zavoreo, and Ludovico Furlanetto from 1787, in detail

SI. 4. Vransko jezero i močvare na karti Francesca Melchiorija, Frane Zavorea i Lodovica Furlanetta iz 1787. godine, isječak

Source / Izvor: NSK, S-JZ-XVIII-22 years, and how they can be correlated with other kinds of demographic, economic, and general statistical data ${ }^{15}$, the authors have carefully selected the most relevant sources ${ }^{16}$. The villages where land reclamation included higher numbers of meadows, fields, and woodlands are positioned around the northwestern extension of the Vrana Lake called Blato, which is only present during part of the year. It primarily comprises the area of contemporary Vrana and Tinj, Jagodnja Donja and Raštanje Donje on the northern part of the Estate, and Turanj, Sveti Filip i Jakov and Biograd na Moru on the southwestern side.

In order to provide the necessary prerequisite for any kind of longitudinal quantitative comparison, the authors tried to equate the scale declared in archive registers for all selected maps. They used calculations from graphical scales (such as Milliaria Italica communia for Jansonius' map, Scala di 20 Miglia Italiane for the map of Melchiori et al., and pertiche padovane for Lodoli's map $)^{17}$. At this

15 HR-DAZD-348, Disposizion Sindici Inquisitori in Dalmazia ... IV, Estate economy, vol. 39, no. 27, 292; HR-DAZD-348, Disposizion Prou. Gen. Grimani ..., IV, Estate economy, vol. 39, no. 27.

16 The number of selected maps for comparison was finally downsized to six: Janssonius' map from 1620 (Fig. 1); Coronelli's map from 1688 (Fig. 2); Santini's map from 1780 (Fig. 3); the map of Melchiori et al. from 1787 (Fig. 4); Lodoli's map from 1756 (Fig. 5); and Borelli Estate's handwritten map of muddy Dissegno (Fig. 6). The comparison with the contemporary situation was based on the topographic map TK25 (Geoportal SGA, n.d.). Insight into the plurality of cartographic analyses of the same or similar (northern Dalmatian) territory but on the basis of various other archival sources can be found in Faričić (2018).

17 By calculating 2,000 pertiche padovane from Lodoli's map into a length of $12,5 \mathrm{~cm}(1 \mathrm{pp}=2.0865 \mathrm{~m})$, the scale was recalculated to approximately 1:33,000 (33,384). For Janssonius' map 12 Milliaria Italica communia equals $7 \mathrm{~cm}$, providing the scale of 1:300,000. In tijekom otprilike 170 godina i pokušaju ih se usporediti s drugim vrstama demografskih, ekonomskih i općih statističkih podataka, ${ }^{15}$ izabrani su najrelevantniji izvori. ${ }^{16}$ Sela u kojima je melioracija uključivala veći broj livada, oranica i šumaraka smještena su uokolo sjeverozapadnoga blatnog i djelomično povremeno poplavljena proširenja jezera Vrana pod imenom Blato. Uključuje prije svega prostore današnjih sela Vrane i Tinja, potom Jagodnje Donje i Raštana Donjih na sjevernom dijelu feuda te Turanj, Sveti Filip i Jakov i Biograd na Moru na jugozapadnoj strani Blata.

U nastojanju da se osiguraju pretpostavke za longitudinalno-kvantitativnu usporedbu provjerana su mjerila korištenih karata koja su navedena u katalozima odgovarajućih fondova. Pritom su se koristila preračunavanja iz grafičkih mjerila (kao što je Milliaria Italica communia na Jansoniusovoj karti, Scala di 20 Miglia Italiane na karti Melchiorija i dr. ili pertiche padovane na Lodolijevoj karti). ${ }^{17}$ Dobiveni rezultati tek su djelomično odgovarali

15 HR-DAZD-348, Disposizion Sindici Inquisitori in Dalmazia ..., IV Ekonomija feuda, sv. 39, IV, br. 27, 292; HR-DAZD-348, Disposizion Prou. Gen. Grimani ..., IV, Ekonomija feuda, sv. 39, br. 27.

16 Izbor karata za usporedbu konačno je sveden na šest: Janssoniusovu kartu iz 1620. (sl. 1), Coronellijevu kartu iz 1688. (sl. 2); Santinijevu kartu iz 1780. (sl. 3), kartu Melchiorija i dr. iz 1787. (s1. 4), Lodolijevu kartu iz 1756. (sl. 5) te rukopisnu kartu blata i močvara posjeda Borelli Dissegno ... (sl. 6). Pri usporedbi s današnjim izgledom toga prostora korištena je topografska karta TK25 (Geoportal DGU, n.d.). Za usporedbu mogućnosti analize kartografske građe približno istoga prostora, ali na temelju različite arhivske građe konzultirati Faričića (2018).

17 Izračunom 2000 jedinica pertiche padovane s Lodolijeve karte, što je odgovaralo duljini od 12,5 $\mathrm{cm}(1 \mathrm{pp}=2,0865 \mathrm{~m})$, dobiveno je približno mjerilo 1:33 000 (preciznije 33 384). Na Janssoniusovoj karti 12 Milliaria Italica communia iznosi $7 \mathrm{~cm}$, što odgovara mjerilu 
stage, it became obvious that certain obstacles for further quantitative analysis were likely. Namely, the attempt to overlap similar scale maps using AutoCAD Raster Design revealed immense spatial deformation of the represented area, due primarily to non-unified and selectively-applied scale concepts in these early-modern maps ${ }^{18}$. However, the scales were not expected to be uniform and these maps were issued in an unknown map projection (in a modern sense) without a coordinate-system grid. Thus, the selected maps had to be rejected as inappropriate for further quantitative comparison using computer programs. Besides the aforementioned analytical problems encountered while working with cartographic sources, the research surprisingly revealed discrepancies between different narrative sources of (nearly) the same provenance, or by authors from the same "side". Due to variations in methodology of data collection, two types of Venetian state officials (Sindici inquisitori and Provveditori generali) unexpectedly offered a significantly different number records for the drained lands of Tinj and Vrana in period of 1752 to 1755 . Such deterioration or decrease recorded in the data is highly suspect, especially regarding the improvement of life conditions and increases in the average number of family members stated for Tinj during the same period.

\section{Discussion: qualitative description of demographic and other statistical elements from observed maps}

When further quantitative comparative analysis of medium scale maps became extremely challenging, even if only used to quantitatively strengthen the numerical demographic and economic statis-

\footnotetext{
spite of the catalogue declaration of the 1:300,000 scale for the map of Melchiori et al., and even recalculation of 20 Miglia Italiane, which equals $10,4 \mathrm{~cm}(1 \mathrm{MI}=1,856 \mathrm{~m})$, later specific calculation determined the actual scale to be $1: 350,000$. Nominal units of historical measures are stated according to Slukan Altić (2003, 63-64).

18 The phenomenon of inconsistency of the early maps which had contributed to their questionable comparability was theoretically known as "incoherent" or "sequential scale" systems of pre-modern, Ancien Regime maps. However, the cartographic production methods of the time usually represented the most accurate geographical and cartographic knowledge and ideas, and should be contextualised within the resources of its time, rather than against contemporary cartographic practices (Mlinarić and Miletić Drder, 2017, 18-25).
}

mjerilima zabilježenim u registrima fondova koji karte čuvaju. Već je u toj fazi postalo razvidno da će postojati određene zapreke provođenju daljnje kvantitativne analize. Konkretno, pokušaj preklapanja karata sličnih mjerila primjenom programa AutoCAD Raster Design pokazao je značajne prostorne deformacije prikazanoga prostora. Razlog prvenstveno leži u izostanku unificiranoga koncepta mjerila ili njegove selektivne primjene na ranonovovjekovnim kartama. ${ }^{18}$ Premda se potpuna uniformnost mjerila nije mogla očekivati, nisu poznate ni kartografske projekcije u kojima su izrađene karte te je izostavljena i koordinatna mreža. Time su izabrane karte morale biti odbačene kao nepodobne za provođenje daljnje kvantitativne usporedbe korištenjem računalnih programa. Osim analitičkih problema s kartografskom građom, istraživanje je pokazalo čak i određene nepodudarnosti narativnih izvora koji imaju gotovo istu provenijenciju (autora), odnosno nastale su s iste „strane” granice. Zahvaljujući razlikama u metodologiji prikupljanja podataka, dvije su različite mletačke administrativne službe (Sindici inquisitori i Provveditori generali), primjerice, prilično neočekivano skupile bitno različite brojčane podatke o isušenim tlima u Tinju i Vrani za 1752. i 1755. godinu. Primjetno brojčano smanjenje u kategoriji melioriranoga područja sigurno je prilično upitan podatak, posebno s obzirom na porast kvalitete životnih uvjeta, kao i brojčano povećanje prosječne obitelji, koje u istom razdoblju izvori bilježe u Tinju.

\section{Rasprava: Kvalitativni opis demografskih i ostalih statističkih elemenata s izabranih karata}

S obzirom na to da se daljnja kvantitativna komparativna analiza karata srednjih mjerila nametnula kao izrazito izazovan cilj, čak i kad služe kao kvantitativna potvrda demografske i ekonomske statisti-

1:300 000. Unatoč tomu što je za kartu Melchiorija i dr. u katalogu deklarirano mjerilo 1:300 000, preračunavanjem 20 miglia italiane, što iznosi 10,4 cm $(1 \mathrm{MI}=1856 \mathrm{~m})$, dobiveno je da je mjerilo karte približno 1:350 000. Vrijednosti starih mjera preuzete su iz Slukan Altić (2003, 63-64).

18 Neujednačenost ranonovovjekovnih karata doprinijela je diskutabilnoj mogućnosti njihove usporedbe, a u kartografskoj teoriji poznata je pod pojmom „nedosljednosti” ili „parcijalnosti mjerila” na predmodernim kartama nastalim u razdoblju ancien regime. Usprkos tomu, kartografska produkcija toga vremena obično donosi najaktualnija geografska znanja i ideje pa je treba kontekstualizirati u okvirima mogućnosti toga vremena, a ne dosega kartografske produkcije danas (Mlinarić i Miletić Drder, 2017, 18-25)
Early modern

Dalmatian

landscape and

demographic

changes in the

multiple borderland

area: cartographic

vs. statistical data

Ranonovovjekovne okolišne i

demografske

promjene na

dalmatinskom

višestrukom pograničju: usporedba

kartografskih i statističkih podataka 
GEOGRAFSKI

GLASNIK

82/1,35-58 (2020.) tics and tax lists, this research became much more grounded in qualitative analysis. Cartographic data visualisation of changes caused by water source and channel regulation and corresponding arable land extension as prerequisite conditions of demographic growth, was an optional but significant clue, even if portrayed by description and additional longitudinal comparison of arable land (representing economic prospects) on observed maps ${ }^{19}$.

Regardless of differences in time of production, and therefore in the non-standardised manner of spatial presentation, all maps, except Santini's (Fig. 3) recorded the muddy area Blato with its specific vegetation concentrated around two, three, or four dominant streams or creeks. These were the northeastern Stabanj or Kakma where we find the contemporary lateral channel, recorded on all four maps, then Jablanac and Vrbica further southwest (Fig. 1 and 2), and finally westernmost Kotarka, also recorded on all maps. Jansonius's depiction of Ottoman holdings from the first half of the $17^{\text {th }}$ century, or villages marked with the Ottoman crescent moon, recorded four streams positioned almost parallel when approaching Vrana Lake. This map described the marshland of Rogovo (Rogouo Paludi) further out from the perimeter of Blato, with the strong influx of water from the southeast (Varceuo or Vrčevo), transported by the river or a stronger stream and positioned where the contemporary main channel or Kotarka is located. Coronelli's representation (Fig. 2) recorded marshes (Paludi) with specific vegetation and also three streams, which supplied Blato. This might represent an expected and logical inter-phase of the melioration processes on the Vrana Estate, i.e. a transitional state between Janssonius' map and Melchiori et al.'s map. As an official Venetian cartographer, Coronelli personally noted or (from other cartographic sources) recognised the importance of Kakma's water sources, which he exaggerated and underlined similarly to the engineers who mapped Vrana hydrography for Count Borelli a century later (Fig. 5 and 6). Santini's map is also inferior to the

19 Similar phenomena were revealed during the correlation of changes in the natural and cultural environment for the same period in central Dalmatia (Fuerst-Bjeliš, 2003). Research methodologies, such as comparisons of narative sources (travel chronicles), cadastral and cartographic sources in search of environmental changes, and spatial data analysis using GIS technology for the Dalmatian Hinterland, were applied in 2011 by Fuerst-Bjeliš et al. See also Blaće (2019). ke poput popisa plaćanja poreza, ovo je istraživanje prije svega utemeljeno na kvalitativnoj analizi. Kartografska vizualizacija podataka o promjenama uzrokovanim regulacijom vodotoka i uređivanjem kanala te pratećim proširenjem obradivoga tla kao preduvjetima demografskoga i ekonomskoga rasta bila je znakovita indikacija napretka, a utvrđena je čak i na osnovi opisa i dodatne longitudinalne usporedbe obradive zemlje prikazane na kartama. ${ }^{19}$

Bez obzira na razliku u vremenu izrade i nestandardiziranom načinu prikazivanja prostora svi su, osim Santinija (sl. 3), zabilježili područje Blata sa specifičnom vegetacijom koncentriranom oko dvaju, triju ili četiriju dominantnih potoka ili rječica. Sjeveroistočno je smješten Stabanj ili Kakma, na položaju današnjega lateralnog kanala, koji je zabilježen na svim četirima kartama, zatim su jugozapadno ucrtani Jablanac i Vrbica (sl. 1 i 2) te konačno najzapadnije Kotarka, također prikazana na svim kartama. Jansoniusov prikaz osmanskoga posjeda iz 17. stoljeća, odnosno sela označenih osmanskim simbolom polumjeseca, zabilježio je četiri vodotoka na močvarnom tlu, smještena gotovo paralelno na prilazu Vranskom jezeru. $\mathrm{Na}$ karti je dokumentirano močvarno zemljište Rogova (Rogouo Paludi) u široj okolici Blata, sa snažnim prilivom vode s područja JI (Varceuo ili brdo Vrčevo). Te vode stižu rijekom ili jačim potokom, koji se nalazi na mjestu današnjega Glavnog kanala ili Kotarke. Coronellijev prikaz (sl. 2) zabilježio je močvare (Paludi) sa specifičnom vegetacijom, ali je smanjio broj na tri potoka koji su opskrbljivali močvarni prostor Blata. Taj bi prikaz mogao predstavljati očekivanu i logičnu međufazu tijekom procesa melioracije na feudu, prijelaz od Janssoniusa do Melchiorija i dr. Kao službeni mletački kartograf, Coronelli je uočio ili pak na nekom od korištenih kartografskih izvora prepoznao važnost izvora u Kakmi, koji je preuveličao i naglasio slično kao i inženjeri koji su stoljeće kasnije kartirali hidrografske objekte Vrane za grofa Borellija (sl. 5 i 6). Santinijeva karta inferiorna je istodobnom

\footnotetext{
19 Slično je zamijećeno prilikom korelacije promjene prirodnoga kulturnoga okoliša u središnjoj Dalmaciji istoga razdoblja (FuerstBjeliš, 2003). Komparativnu analizu narativnih (putopisi), katastarskih i kartografskih izvora te prostornu analizu podataka pomoću GIS tehnologije u metodologiji istraživanja promjena okoliša za prostor dalmatinske unutrašnjosti još 2011. godine primijenili su Fuerst-Bjeliš i dr. Vidjeti i Blaće (2019).
} 
map of Melchiori et al. as a contemporary product, in that it failed to record the mud flats and vegetation of Blato and only showed two dominant streams. This can be explained by the inadequate fieldwork of Santini (Fig. 3) in comparison to the much better topographic achievement of Melchiori's team. Reduction of the main streams supplying the Lake from four (Janssonius) to two (Melchiori et al.) distinct water sources indicates possible improvements of the temporary marshland meadows of Blato or some kind of land regulation and/or melioration. It may also represent the politically or psychologically indicative image of a deteriorated landscape, as it was under Ottoman dominion (when Janssonius' map was drawn).

The authors additionally explored the analytic possibilities of other large-scale maps of the Vrana Estate (with surprisingly similar scale for early maps, but still inadequate for quantitative analysis $)^{20}$, along with other economic and demographic statistics of different origin ${ }^{21}$, collected and preserved thanks to the Borelli family archive - a precious source for such an early and generally poorly-documented period. In terms of descriptive comparison, the other two maps (Lodoli's and the mud flat manuscript map ${ }^{22}$ are more reliable and detailed for this kind of analysis, not just due to their large scale but also thanks to the more accurate sources they were (probably) based upon. As it was deliberately drawn by specially engaged engineers and cartographers to illustrate the economic and ecological situation on the Vrana Estate, these maps offered a rich and diversified network of small mud flats, streams, and creeks all around the Blato area. Categories of land-use and even settlement structure ${ }^{23}$ were much more structured and separately summarised in numerical statistics on Lodoli's map, with categories such as fields and

20 They include a cadastral map (HR-DAZD-6, Venetian cadastre, Grimani Cadastre Maps, no. 511), showing the District of Zadar from 1709 and hand written sketches of the Vrana mud flats (Blato) (HR-DAZD-248, $2, \mathrm{C}, 9$; ibid 2, C, 12) that show landscape changes over time.

21 An example is the feudal fiscal obligation list of pasture taxation (berbatico) (HR-DAZD-348, 1795, vol. 6, 2).

22 HR-DAZD-348, 2, C, 8

23 The population numbers themselves are indicative of not just the demographic trends, but also of corresponding information like form (indicating the time of founding), dimension, or practical effectiveness of local settlement patterns (Petrić, 2012, 340-341; HR-DAZD-348, IV, 97; HR-DAZD-348, 2, 38, 1 (Vrana). postignuću Melchiorija i dr. jer izostavlja močvarna zemljišta i vegetaciju Blata te inzistira na svega dva dominantna potoka. Razlog se može pronaći u nedostatnom Santinijevu terenskom radu (sl. 3) u usporedbi s puno boljim topografskim postignućem Melchiorijeva tima. Smanjenje broja glavnih vodotoka koji opskrbljuju jezero s četiri (Janssonius) na dva (Melchiori i dr.) upućuje na moguća isušivanja povremenih močvarnih polja Blata ili provođenje određene vrste uređenja zemljišta. Također može biti politički ili psihološki indikativan odraz narušena (devastirana) krajolika s obzirom na to da je u doba koje prikazuje bio pod osmanskom vlašću (Janssoniusova karta).

U radu su dodatno istražene analitičke mogućnosti i nekih drugih karata vranskoga posjeda krupnijih mjerila s iznenađujuće sličnim mjerilima za tako rane karte, premda su i dalje ostale neprikladne za kvantitativnu analizu, ${ }^{20}$ kao i s različitim ekonomskim i demografskim statističkim podatcima drugoga podrijetla. ${ }^{21}$ Oni su prikupljeni i sačuvani zahvaljujući arhivu obitelji Borelli kao dragocjenom vrelu za tako rano i uglavnom loše dokumentirano razdoblje. S aspekta deskriptivne usporedbe sljedeće su se dvije karte (Lodolijeva i rukopisna karta močvarnoga zemljišta ${ }^{22}$ ) potvrdile kao pouzdanije i detaljnije za takve vrste analiza, ne samo zbog krupnijega mjerila već i zahvaljujući točnijim izvorima na kojima su (najvjerojatnije) temeljene. Ciljano su ih izradili posebno angažirani inženjeri i kartografi da bi ilustrirali ekonomsko i ekološko stanje na vranskom posjedu te su prikazali bogatu i raznorodnu mrežu malih močvarnih potoka i rječica na cijelom područja Blata. Kategorije korištenja zemljišta, pa čak i strukture naselja ${ }^{23}$ već su detaljnije te su zasebno sažete u popisu brojčanih podataka na Lodolijevoj karti. Navedene su kategorije oranica i vinograda, livada, šuma i pašnjaka, močvara odnosno

20 Na temelju katastarske karte (HR-DAZD-6, Mletački katastar, Mape Grimani, br. 511) koja prikazuje Zadarsko okružje iz 1709. godine i rukopisne skice močvara oko Blata (HR-DAZD-348, 2, C, 9; ibid 2, $\mathrm{C}, 12)$ prikazane su promjene krajolika tijekom godina.

21 Primjer je popis feudalnih fiskalnih obveza poreza na ispašu (herbatico) (HR-DAZD-348, 1795, sv. 6, 2).

\section{HR-DAZD-348, 2, C, 8.}

23 Broj stanovnika upućuje ne samo na demografske trendove već i nekim detaljima (poput oblika naselja) indicira, primjerice, vrijeme osnivanja, dimenziju ili praktičnu svrhu određenoga naselja (Petrić, 2012, 340-341; HR-DAZD-348, IV, 97; HR-DAZD-348, 2, 38, 1 (Vrana).
Early modern

Dalmatian

landscape and

demographic

changes in the

multiple borderland

area: cartographic

vs. statistical data

Ranonovovjekovne okolišne i

demografske

promjene na

dalmatinskom

višestrukom pograničju: usporedba

kartografskih i

statističkih podataka 
GEOGRAFSKI

GLASNIK

82/1,35-58 (2020.) vineyards, meadows, woods and pastures, marshes/ moors, uncultivated and unusable, and unused but able to be cultivated (Fig. 5 and 7). Uneven plots which surrounded meandering river flows or roads, unevenly shaped fields, and the illogical mixture of agricultural use all indicated the longevity and multiplicity of legal (and illegal) practices of land use or, in other words, old property and old settlements. In contrast, new settlements and plots are recorded with more even shapes and grades, being either newly-occupied by neighbours or just stolen from the marshes, such as the water sources of the Biba environment or Vrana area. The mapped water features are streams with (typically) karst fluvial regimes of periodic underground flows, depending on contacts of porous (limestone) and more solid soil sediments, whereby direct collision of these two materials in underground waters burst out as new currents or karst wells. The most endangered were the closest villages to the marshy meadows, inhabitants of Tinj (Lissane) ${ }^{24}$ and Jagodnja Donja (Giagodgna) in this case, but as two mud maps indicate, some agricultural and irrigational attempts have already been done around Kakma and in the northwestern corner of Blato where the map recorded some new channels (Fosso nuovo) and newly meliorated land (Fig. 6). This area was surprisingly not recorded as land given to the closest villages: Jagodnja; Tinj; or Raštane. In contrast, these marshlands and pasture meadows, with several new water mills, were the home of inhabitants of distant Biograd na Moru, Turanj, and Sveti Filip i Jakov, who were known to live longer and healthier lives and had demographically and economically better prospects ${ }^{25}$. Similarly, the new southern land acquisition of the Estate (Praderia) that had been "stolen from the grasp of the swamp" was attributed to inhabitants of Biograd na Moru instead of to those of the closer Sveti Filip i Jakov, reflecting the early stage of social stratification among settlements and inhabitants of the Vrana Estate.

24 Such an irrigated arable land extension, along with better village prospects, was a crucial example of development possibilities especially in case of Tinj. It was characterised by a significant increase in arable land in statistical sources, and followed with immense population growth (Feudi in Dalmazia sotto il governo veneto, ZKZ, Ms. 110, 88; HR-DAZD-348, Albero Genealogico di Tign, vol. 98, no. 72/1-30). See Mlinarić and Župarić-Iljić (2017, 49-50).

25 See sources in footnote 15; Mlinarić (2006, 46-51). blata, neobrađenoga i neupotrebljivoga zemljišta te neobrađenoga zemljišta koje bi se moglo obraditi (sl. 5 i 7). Nejednake parcele okruživali su vijugavi vodotoci ili ceste, a zajedno s nepravilno oblikovanim poljima i nelogičnom mješavinom poljoprivrednih kultura upućivale su na njihovu starost odnosno na višestrukost pravnih (pa i ilegalnih) praksi korištenja zemljišta. Drugim riječima, upućivale su na to da je riječ o starom posjedu i starim naseljima. Nova naselja i čestice su, potpuno suprotno, definirani pravilnijim linijama i oblicima bez obzira na to jesu li nedavno osvojeni od susjeda ili su oteti močvari. Kao primjer mogu poslužiti čestice i vodotoci u porječju Bibe odnosno na cijelom područja Vrane. Kartirane vodotoke obilježavali su tipično krški fluvijalni režimi periodičnih podzemnih tokova koji su ovisili o kontaktima poroznih (vapnenačkih) i čvršćih sedimenata tla. Na mjestima konkretnih dodira tih dvaju materijala podzemne su vode izvirale kao novi potoci ili krški izvori. Najugroženiji su, baš stoga što su bili najbliži močvarnim poljima, ponovno bili stanovnici Tinja (Lissane) ${ }^{24} \mathrm{i}$ Jagodnje Donje (Giagodgna). No kako pokazuju rukopisne karte močvara, određeni su poljoprivredni i irigacijski radovi u to vrijeme već realizirani oko Kakme i u sjeverozapadnom dijelu Blata, gdje je karta zabilježila nekoliko novih kanala (Fosso nuovo) i novoisušena tla (sl. 6). Iznenađuje međutim da ovo područje nije dokumentirano kao posjed stanovnika najbližih sela Jagodnje, Tinja ili Raštana. Suprotno očekivanjima te močvare i pašnjaci, s nekoliko novih mlinova, bili su u posjedu stanovnika udaljenih naselja Biograda na Moru, Turnja te Svetog Filipa i Jakova. Upravo su ti stanovnici bili poznati po većoj duljini i kvaliteti života, s boljom demografskom i ekonomskom perspektivom. ${ }^{25}$ Slično tomu je i južno novostečeno zemljište posjeda (Praderia), nakon što je zaustavljeno močvarno plavljenje, prepušteno stanovnicima Biograda na Moru, a nije dano na korištenje stanovnicima bližega naselja Sveti Filip i Jakov. Takva podjela zemlje predstavljala je ranu fazu društvene stratifikacije među stanovnicima i naseljima vranskoga posjeda.

\footnotetext{
24 Širenje obradivoga zemljišta melioracijom, kao i svjetlija razvojna perspektiva koju je neko selo imalo bili su presudni u optimiziranju razvojnih kapaciteta, posebno u slučaju Tinja. Sudeći prema statističkim podatcima, Tinj je obilježilo značajno povećanje obradive zemlje koje je pratio porast stanovništva (Feudi in Dalmazia sotto il governo veneto, ZKZ, Ms.110, 88; HR-DAZD-348, Albero Genealogico di Tign, kut. 98 br. 72/1-30). Vidi Mlinarić i Župarić-Iljić (2017, 49-50).
}

25 Vidi izvore u bilješci 15; Mlinarić (2006, 46-51). 


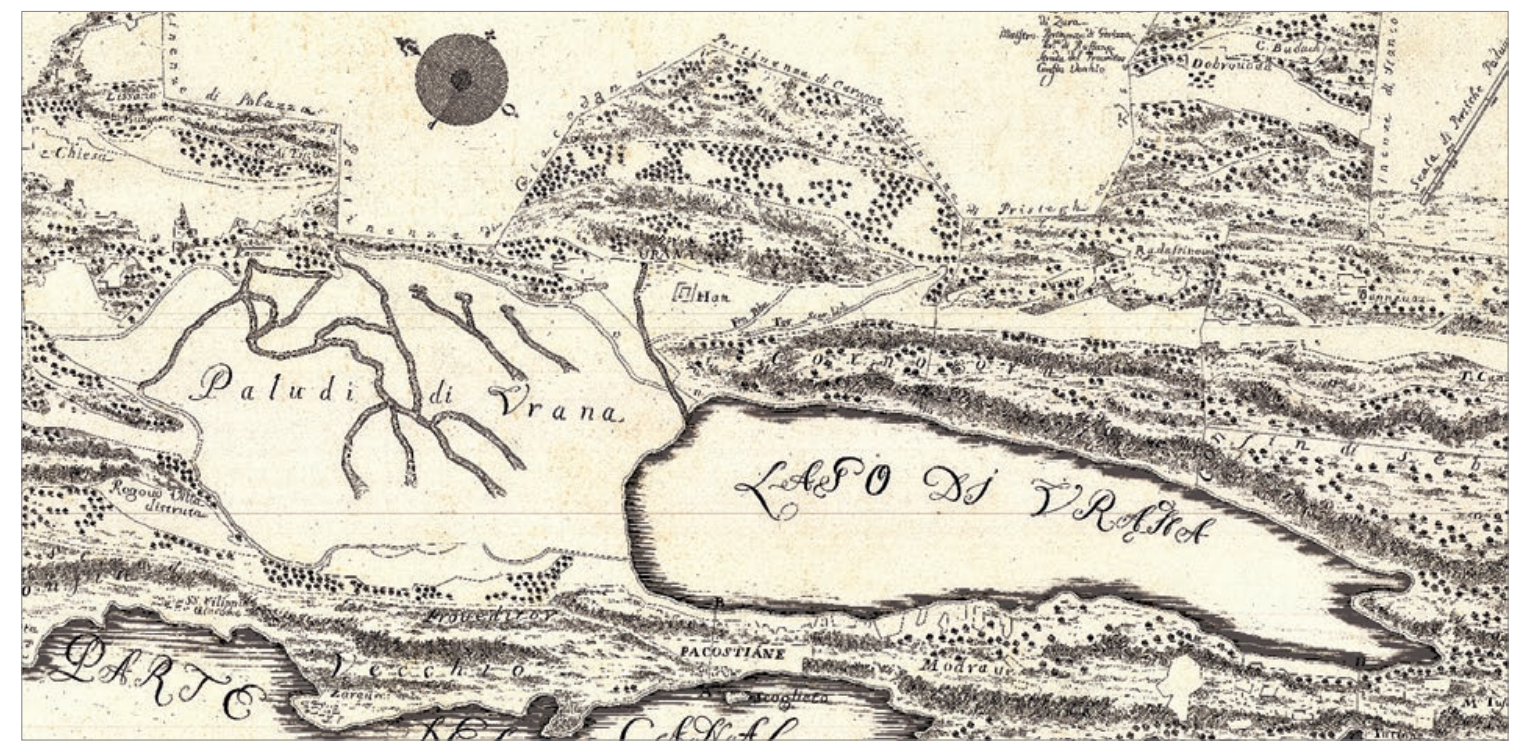

D. Mlinarić I. Kljajić

Early modern

Dalmatian

landscape and

demographic

changes in the

multiple borderland

area: cartographic

vs. statistical data

Ranonovovjekovne okolišne i

demografske

promjene na

dalmatinskom

višestrukom

pograničju:

usporedba

kartografskih i statističkih podataka

Fig. 5 Map of the Vrana Estate made by G. Battista Lodoli in 1756, in detail

SI. 5. Karta vranskoga posjeda G. Battiste Lodolija iz 1756., isječak

Source: HR-DAZD-383, Map collection, no. 2.2.9.

Izvor: HR-DAZD-383, Kartografska zbirka, br. 2.2.9

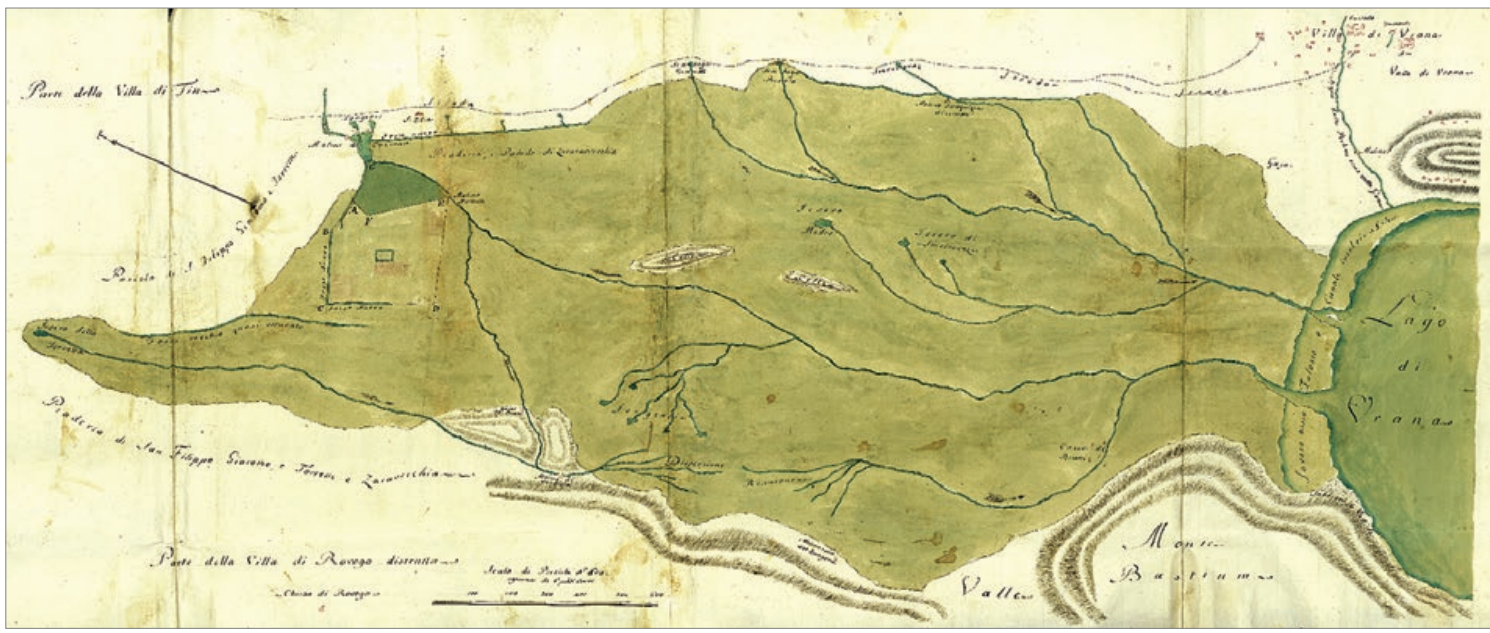

Fig. 6 Water streams of the Vrana Estate, in detail

SI. 6. Vodotoci vranskoga posjeda, isječak

Source / Izvor: HR-DAZD-348, 2, C, 8

In spite of the 3,000 inhabitants of the Vrana estate, who lived on a territory of 40,881 campi padovani ${ }^{26}$, as recorded on Lodoli's map (Fig. 5), the liminal position of Vrana as a part of Venetian overseas territory (eastern Adriatic) consequently lessened the support of the central administra-

26 One campo padovano equals $38.53 \mathrm{~m}^{2}$ (Slukan Altić, 2003, 64).
Unatoč broju od 3000 stanovnika vranskoga posjeda, koji su živjeli na području od 40881 padovanskih kampa, ${ }^{26}$ što je zabilježeno na Lodolijevoj karti (sl. 5), vranski je posjed više obilježio njegov rubni položaj mletačkoga prekomorskog posjeda na istočnom Jadranu. On je posljedično doveo do slabije potpore

26 Jedan padovanski kamp iznosio je 38,53 m² (Slukan Altić, 2003, 64). 
HRVATSKI

GEOGRAFSKI

GLASNIK

82/1,35-58 (2020.)

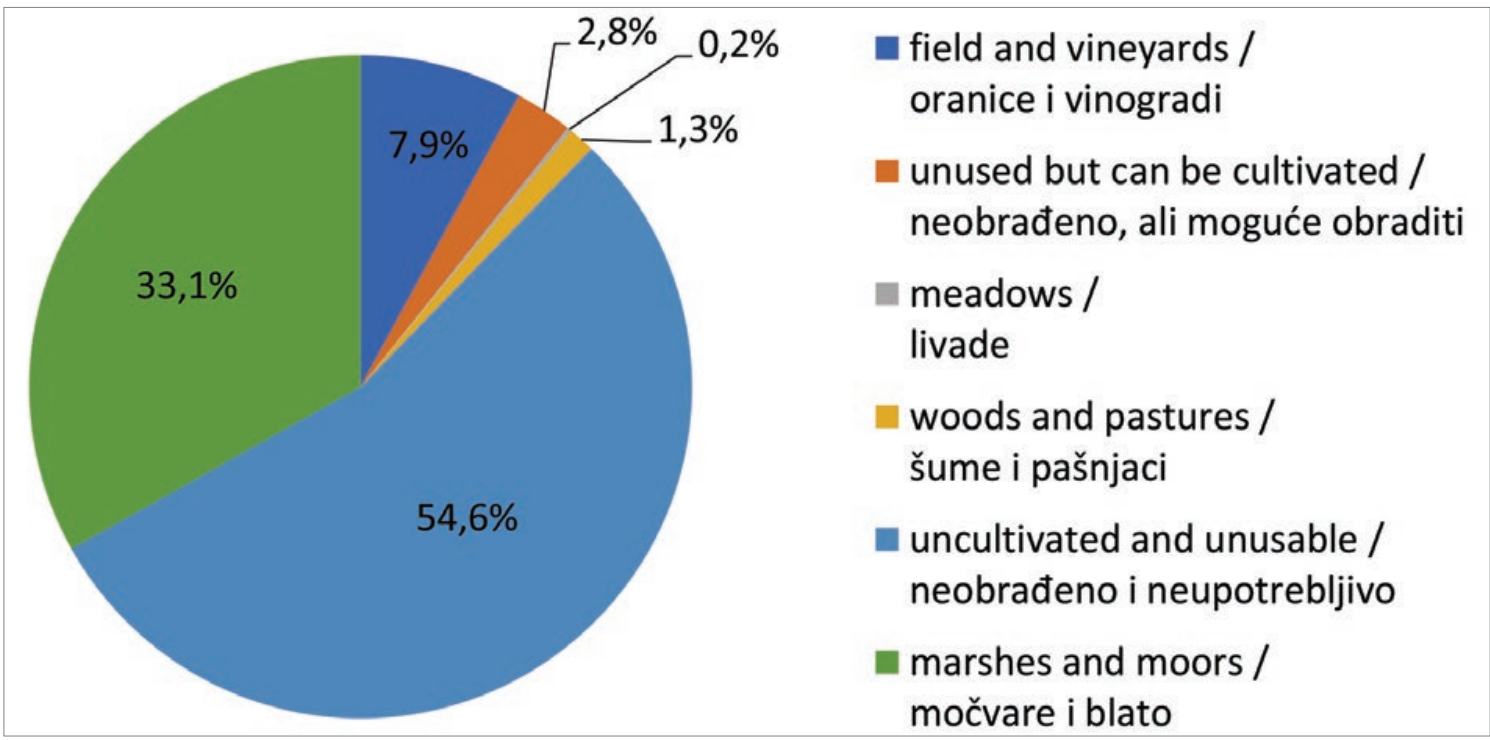

Fig. 7 Categories of land-use at the Vrana Estate

SI. 7. Kategorije korištenja zemljišta na vranskom posjedu

Source: Calculations based on data found on Lodoli's map (HR-DAZD-383, Map collection, no. 2.2.9)

Izvor: Izračun temeljen na podatcima s Lodolijeve karte (HR-DAZD, 383, Kartografska zbirka, br. 2.2.9)

tion in various situations involving social distress ${ }^{27}$. The same source proved that more than half of the whole property $(22,328$ campi) was comprised of uncultivated or unusable land ${ }^{28}$, while an additional 13,540 campi were covered with marshes and moors (Fig. 7). Since only 3,248 campi were initially used as vineyards or fields, the idea of starting projects to increase the arable land was an attractive and reasonable option. Although this was not exclusively Borelli's idea, abandoned parcels were also used as an attractive migration pull factor for agrarian rural migrants. In return, they became, along with their regular feudal working obligations, burdened with additional duty of auxiliary local military footmen. Such newly reclaimed terrain served as an attractive

27 Conversely, during the sustained threat of Ottoman (re)conquest or at least cross-border raiding, Venetian local officials did not see any benefit in draining marshland near the border. Furthermore, the absence of state management or conservation efforts in that regard can be explained partly by the state's defence decisions to let marshlands serve as a protective barrier against potential Ottoman attacks in times of turmoil on eastern Adriatic battlefield(s) (Mlinarić, 2006, 47). Such a practice of turning economically disadvantageous marshes into defensive areas was widely used (Squatriti, 1992, 2).

28 Due to constantly deposited silt sediments in numerous watercourses, lowland topographies were among the elements that were rarely recorded but often and easily changed and were therefore drawn differently on various maps. središnje uprave u različitim vrstama socijalnih nevolja. ${ }^{27}$ Isti izvor dokumentirao je da je više od polovice cjelokupnoga posjeda (22 $328 \mathrm{kampa}$ ) činilo neobrađeno ili neiskorišteno tlo, ${ }^{28}$ dok je dodatnih 13540 kampa bilo prekriveno močvarama i blatom (sl. 7). Budući da je samo 3248 kampa korišteno kao vinogradi ili oranice, zamisao pokretanja projekata isušivanja u cilju povećanja površine obradive zemlje bila je vrlo utemeljena. Iako melioracija nije bila isključivo inovativnost Borellijevih, oni su iskoristili zapušteni posjed kao atraktivan čimbenik privlačenja ruralnih doseljenika. U zamjenu su oni uz svoje redovne feudalne radne obveze pristali obnašati dodatne dužnosti članova pomoćnih lokalnih vojnih jedinica. U tom je smislu novouređeno zemljište poslužilo kao atraktiv-

27 Upravo suprotno, tijekom dugoga trajanja prijetnje od eventualne osmanske rekonkviste ili zbog kratkotrajnih destruktivnih prekograničnih pljačkaških akcija mletački lokalni dužnosnici nisu smatrali isušivanje pograničnoga močvarnog područja korisnim. Nadalje, nepostojanje državnoga upravljanja močvarom i održavanja kanala može se dijelom objasniti željom da močvara bude barijera koja služi kao zaštita od potencijalnih osmanlijskih napada u doba različitih previranja na istočnom Jadranu (Mlinarić, 2006, 47). Takva je praksa pretvaranja ekonomski nepovoljnih močvara u obrambeni štit bila i inače široko rasprostranjena (Squatriti, 1992, 2).

28 Zbog stalnoga taloženja sedimenata i mulja u brojnim vodotocima nizinska područja bila su među elementima koji su lako i često mijenjani premda su na kartama rijetko bilježena ili različito ucrtavana. 
"salary" for Vlachs (Morlachs), along with the other tax, administrative, and legal benefits they received (Stanojević, 2004, 178; Mayhew, 2008, 166-169; Hafizović, 2016, 20). Fertile land, in that sense, mitigated depopulation, substituted human losses, and enable further growth (Mayhew 2008, 62; Rimac and Mladineo 2009,16). Accordingly, drainage works on the Vrana estate, as ecologic and economic projects, profoundly changed population trends but also introduced some long-term changes in the cultural landscape.

An additional problem is the reliability of early modern statistical data, which was sometimes highly questionable. For instance, the numerical statistics on Lodoli's map from 1756 recorded approximately 40,000 campi padovani of total land at the property, while the comparative and almost simultaneously composed cadastral survey (Cadastre Grimani) ${ }^{29}$ revealed significantly larger numbers (53,324 campi padovani). Such data incompatibility can be explained by the vague interest and overall scarcity of relevant economic or statistical data of civil provenance (feudal administration) in Venetian Dalmatia, contrary to the more extensive statistical records of important military objects (e.g. fortifications) of the time. Therefore, the Vrana Estate's archive represents an exceptional, carefully-collected, and preserved set of feudal management data. Regardless of this advantage, the aforementioned plurality of contradicting information confirms the significant increase of newly drained arable land on one hand, especially in comparison with the Cadastre Vendramin data from 50 years earlier, in contrast with the questionable consistency of statistics. In terms of reclamation, Vendramin had counted 1,026 campi padovani of arable land in 1709 for Vrana itself in their recording or extension of fertile land report, while the extended area, according to Cadastre Grimani from 1756, comprised 1,506 campi. A similar comparison for the village Tinj, one of the closest to Vrana's mud flats and marshes, recorded an increase from 523 to 2,055 campi padovani. A significant deficit, stated in the document for $\mathrm{Bi}^{-}$ ograd na Moru and its arable parcels, probably had much more to do with legal pattern variations be-

29 See detailed statistics comparison for each of the villages from the Borelli Estate in Mlinarić and Župarić-Iljić (2017, 52-53). na naknada za Morlake, slično kao i neke druge porezne, administrativne i pravne povlastice koje su dobili (Stanojević, 2004, 178; Mayhew, 2008, 166-169; Hafizović, 2016, 20). Plodno tlo omogućilo je ublažavanje depopulacije, pokrivanje ljudskih gubitaka useljavanjem te je omogućavalo daljnji rast (Mayhew 2008, 62; Rimac i Mladineo 2009, 16). Prema tome, projekti melioracije vranskoga posjeda, kao ekološki i ekonomski pothvati duboko su promijenili populacijske trendove, ali i uveli neke dugoročne promjene $u$ kulturnom krajoliku, poput vjerske sastavnice.

Dodatan problem ovakve statističke analize bila je dvojbena pouzdanost ranonovjekovnih statističkih podataka, koji su katkad vrlo upitni zbog različitih razloga. Na primjer, brojčani podatci na Lodolijevoj karti iz 1756. godine bilježe približno 40000 padovanskih kampa ukupnoga zemljišta na posjedu, dok je gotovo istodobno nastali Grimanijev katastar, ${ }^{29}$ sastavljen na osnovi katastarske izmjere iskazao znatno veće brojke (53 324 padovanskih kampa). Takva neusklađenost podataka može se objasniti slabim interesom popisivača i oskudnim izvorima s relevantnim ekonomskim ili statističkim podatcima feudalne uprave, dakle onima civilnoga podrijetla u mletačkoj Dalmaciji, nasuprot opsežnijim statističkim evidencijama o tada važnim vojnim objektima, primjerice fortifikacijskoj arhitekturi. Stoga je arhivski fond vranskoga posjeda izvanredan, pažljivo prikupljen i sačuvan skup podataka feudalnoga upravljanja. Unatoč toj prednosti spomenuto mnoštvo kontradiktornih podataka s jedne strane potvrđuje značajni rast novoisušenoga obradivog zemljišta, posebno u usporedbi s pola stoljeća starijim podatcima katastra Vendramin, ali s druge strane ponovno dovodi u pitanje dosljednost statistike. Vezano uz isušivanje i melioraciju te proširenje obradivoga tla Vendramin za Vranu 1709. bilježi 1026 padovanskih kampa obradivoga zemljišta, dok je proširenje obradivoga tla, prema Grimanijevu katastru iz 1756. godine, obuhvatilo 1506 kampa. Slična usporedba za jedno od najbližih sela vranskom blatu i močvarama, Tinj, zabilježila je porast s 523 na 2055 padovanskih kampa. Za Biograd na Moru zabilježen je pad obradivoga tla, ali to se vjerojatno, uz različitost dvaju pravnih modela

29 Detaljnu statističku usporedbu za svako selo posjeda vidi u: Mlinarić i Župarić-Iljić (2017, 52-53).
D. Mlinarić I. Kljajić

Early modern

Dalmatian

landscape and

demographic

changes in the

multiple borderland

area: cartographic

vs. statistical data

Ranonovovjekovne okolišne i

demografske

promjene na

dalmatinskom

višestrukom pograničju: usporedba

kartografskih i

statističkih podataka 
HRVATSKI

GEOGRAFSKI

GLASNIK

$82 / 1,35-58(2020$.

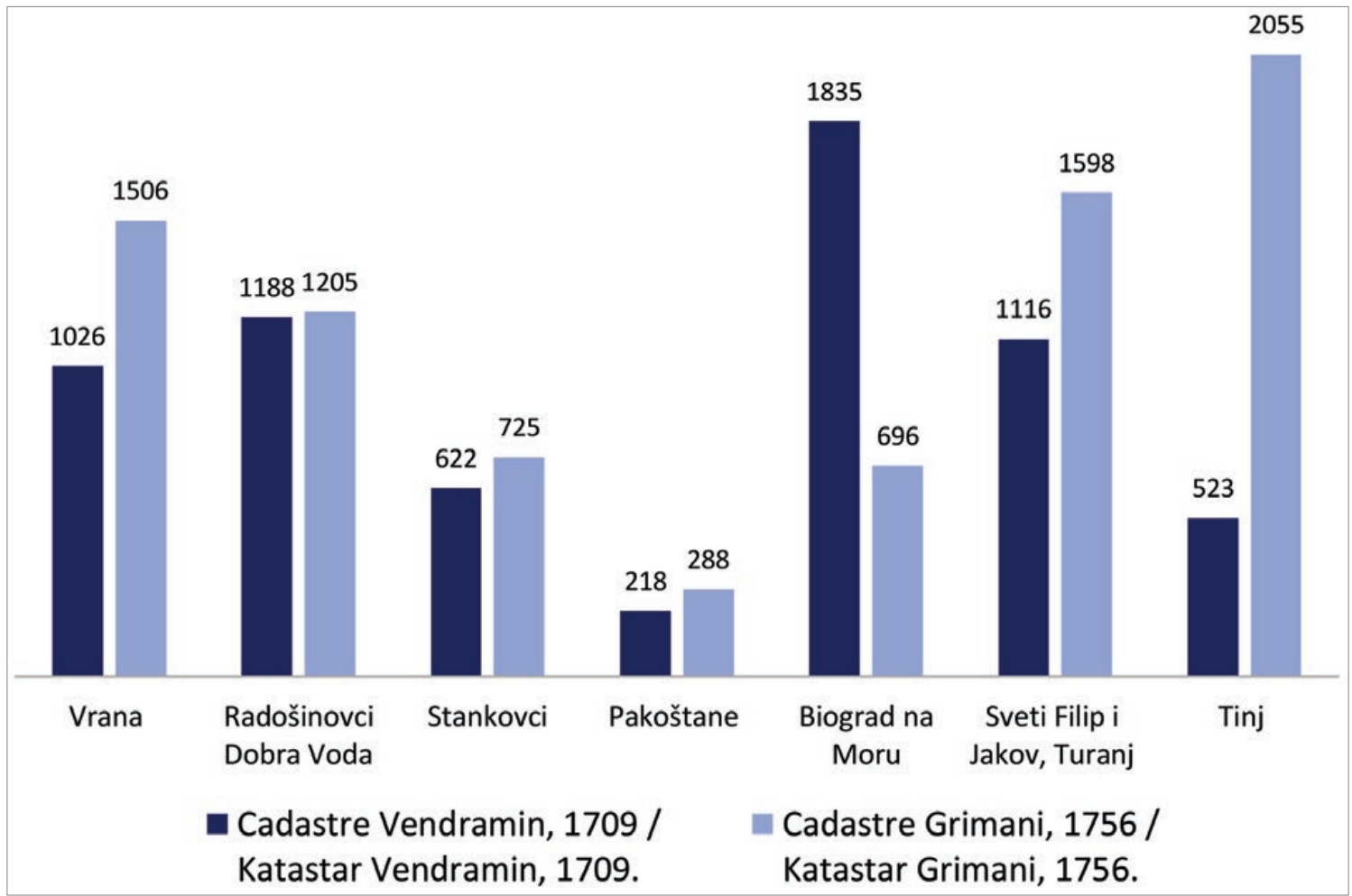

Fig. 8 Comparison of land possessions for each village of the Estate in two Censuses

SI. 8. Usporedba posjedovanja zemljišta za svako selo feuda na temelju dvaju popisa

Source / Izvor: Feudi in Dalmazia sotto il governo veneto, ZKZ, Ms. 110, 88

tween two observed sources, or the restrictive legal practice of attributing newly eradicated fields to settlements with more urban characteristics than to the engineering project itself (Fig. 8).

After Vrana mud flats and marshes, representing more than one-third of the Estate's total territory, were drained, the damp soil improved in quality. Numerous water elements became desiccated after the trenching of a network of channels, including the large Prosika Canal (Tatinje) ${ }^{30}$, which connects Lake Vrana with the Adriatic Sea, representing the grounds for further ecological and economic proliferation (Peričić, 1971,396). Based on cadastre comparison, the expected demographic prosperity did not come, at least not for the Vrana or Sveti Filip i Jakov communities (Fig. 9).

30 It was the crucial part of the 1760 Vrana eradication project, with an additional annex trenched in 1770 s, when the channel reached the dimensions of $850 \mathrm{~m}$ long and $4 \mathrm{~m}$ wide. Its purpose was to drain surplus lowland waters, directing them to the Adriatic Sea (see engineering plans HR-DAZD-348, 4, M, 3; ibid 4, M, 5). koji obilježavaju dva uspoređena izvora, može prije obrazložiti restriktivnijim pravnim dodjeljivanjem novostečene zemlje naseljima s izraženijim urbanim elementima nego podbačajem samih melioracijskih projekata (sl. 8).

Nakon što su vranska blata i močvare, koje čine trećinu ukupnoga teritorija feuda, jednom bile isušene, podigla se kvaliteta vlažnoga prostora. Brojni vodni objekti većinom su isušeni nakon iskopavanja mreže kanala, uključujući i onaj najveći, kanal Prosika (Tatinje), ${ }^{30}$ koji je povezivao Vransko jezero s Jadranskim morem, predstavljajući osnovu za daljnji ekološki, ali i ekonomski uzlet (Peričić, 1971, 396). No iako je bio očekivan, na osnovi katastarske usporedbe, demografski prosperitet nije zabilježen u podatcima, barem ne u slučaju naselja Vrana ili Sv. Filip i Jakov (sl. 9).

30 Bio je ključan dio projekta isušivanja Vrane iz 1760. godine, s dodatnim proširenjem prokopanim 1770-ih, kada je kanal dostigao kapacitet duljine 850 metara $\mathrm{i}$ širine $4 \mathrm{~m}$ da bi prema moru kanalizirao višak vode (vidi planove HR-DAZD-348, 4, M, 3; ibid $4, M, 5)$. 


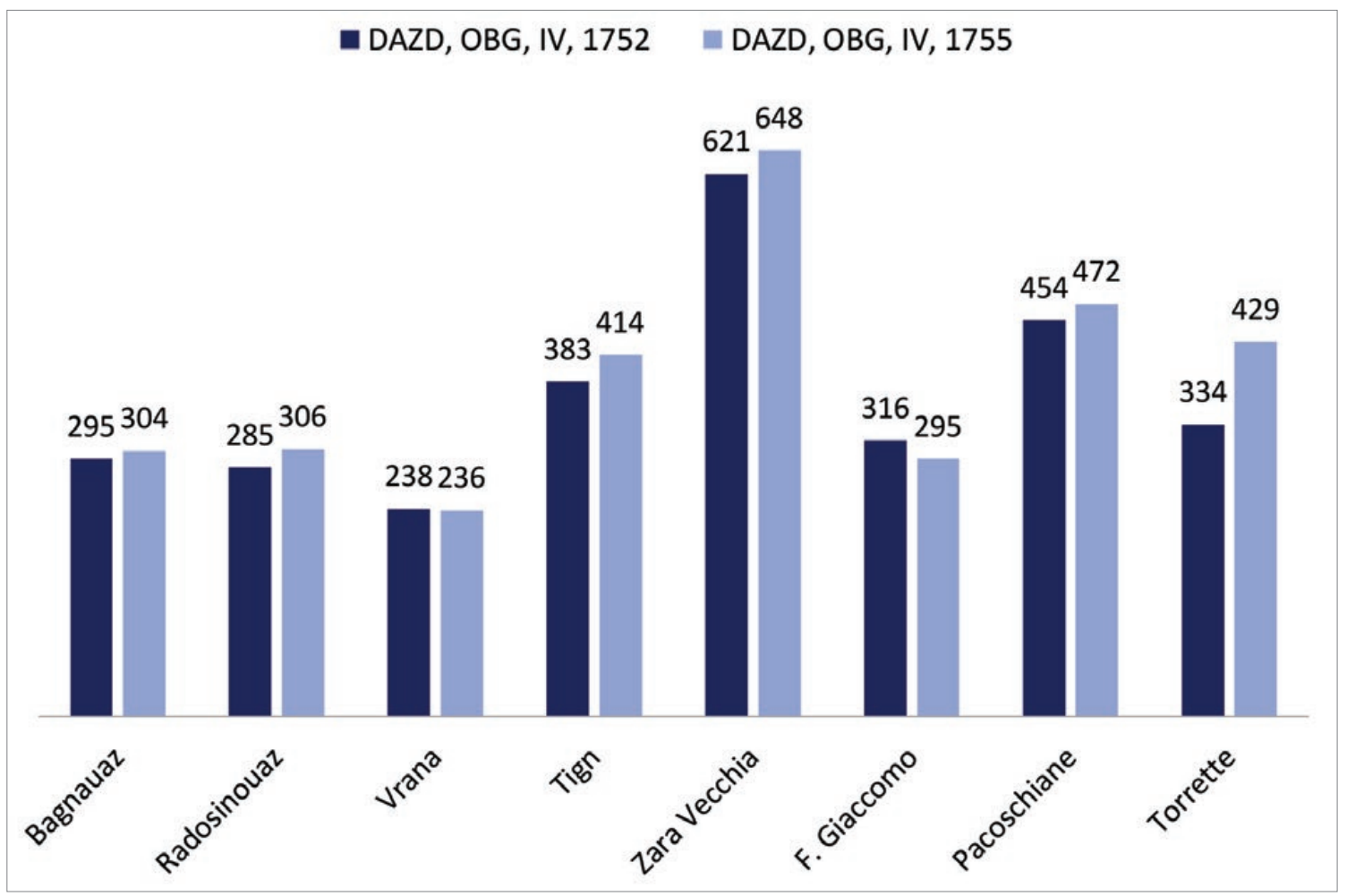

D. Mlinarić I. Kljajić

Early modern

Dalmatian

landscape and

demographic

changes in the

multiple borderland

area: cartographic

vs. statistical data

Ranonovovjekovne okolišne i

demografske

promjene na

dalmatinskom

višestrukom pograničju: usporedba

kartografskih i

statističkih podataka

Fig. 9 Population increase according to two Censuses

Sl. 9. Porast stanovništva prema dvama popisima stanovništva

Source / Izvor: Source: HR-DAZD-348, Disposizion Sindici Inquvisitori in Dalmazia ..., IV, vol. 39, no. 27, 292; HR-DAZD-348, Disposizion Prou. Gen. Grimani .... IV, Estate economy, vol. 39, no. 27

\section{Migrations to the Vrana Estate}

Due to the initial lack of fertile land, statistics (Fig. 9) confirm only gradual demographic growth, followed by migrations of various scope, direction, and intensity ${ }^{31}$. New lands ended up serving as an advantage to attract immigrants, be they domestic inhabitants who relocated after the borderline delimitation ${ }^{32}$, returners from nearby Ottoman serhat, or even Morlach newcomers. The land was used to detain the existing inhabitants and prevent their emigration. Some migrants were emigrants fleeing the war zones and their destructive social consequences or legal particularism, but complex models of spatial mobility also included immigration of "good highlander"

31 See the case study of migration networks in the village Tinj in Mlinarić and Župarić-Iljić (2017, 45-48).

32 In 1699, linea Grimani separated the villages of the Sandžak of Krka, leaving a number of Ottoman subjects under new administrative rule, in this case Venetian (Hafizović, 2016, 15-23).

\section{Migracije na vranskom posjedu}

Uslijed početnoga nedostatka plodne zemlje, odnosno manjka zdrava okoliša bez opasnosti od močvarnih groznica, izvori (sl.9) potvrđuju tek postupni demografski rast, koji su pratile i migracije različitih oblika, smjerova i intenziteta. ${ }^{31}$ Novo je zemljište konačno poslužilo kao mamac privlačenja doseljenika, bilo domicilnoga stanovništva nakon povlačenja linije razgraničenja, ${ }^{32}$ povratnika s osmanskoga serbata ili čak novodoseljenih Morlaka, a koristilo se i za zadržavanje postojećih stanovnika i sprečavanje njihova iseljavanja. Neki od doseljenika prebjegli su iz ratnih zona skrivajući se od destruktivnih socijalnih posljedica ili pravnoga partikularizma. Složeni modeli prostorne pokretljivosti također uključuju i useljava-

31 Studiju migracijske mreže u selu Tinj vidi u: Mlinarić i Župarić-Iljić (2017, 45-48).

32 Godine 1699. linea Grimani razdvojila je sela Krčkoga sandžaka, ostavljajući mnogobrojne osmanske podanike pod novom upravom, u ovom slučaju mletačkom (Hafizović, 2016, 15-23). 
Morlachs, who were (re)colonised from the hilly northwestern area of Bukovica or from the Ottoman borderland (serhat) (Traljić, 1965, 210-212; Mayhew, 2008, 36-37; Rimac and Mladineo, 2009, 19). The full proto-modern (i)mmigration potential of this new arable landscape was also used to attract hinterland Vlach shepherds, i.e. strong and healthy "savages", expected to be less vulnerable to endemic and malaria-like fevers and other diseases (Peričić, 1971, 405). Furthermore, these newcomer Morlachs did not develop a "marshophobic" mentality like the urban elites did (Squatriti, 1992, 5; Mlinarić, 2006, 43-46). At the time, malaria-like diseases ${ }^{33}$ significantly diminished the economic productivity and demographic potential of the population in lowland areas, who were continuously engaged in reclamation actions and drainage projects (Rimac and Mladineo, 2009, 4). These newcomers were primary engaged as a labour force for abandoned village parcels of the estate, even including a small number of colonised peasants from northern Italy (Furlania), or larger number of local relatives of existing inhabitants, who came to Vrana in search of better prospects or as spouses from within the Zadar archipelago or broader hinterland area. Another category of immigrants were mostly transhumant Morlach shepherds from Ravni Kotari (Mlinarić and Župarić-Iljić, 2017, 44-48). To date, researches have agreed that Venetian interest in border stabilisation additionally stimulated sedentary processes among settlers, as well as the intensification of agricultural production and the shaping of a specific cultural landscape (Fuerst-Bjeliš and Zupanc, 2007, 49). Permanent colonisation of Morlachs into the Vrana Estate's villages was conducted in considerable numbers but was not completely successful, partly due to the challenges represented by marshland fevers. Since the exact cause of malaria was unknown

33 At the time prior to the scientific diagnosis of malaria, some diseases related to a certain medium, like water, were conflated with other similar diseases due to their symptoms. Such was the case with the symptoms of dysentery, malaria, or even in some cases of diarrhoea. The clarification was not easy, due to the general exhaustion of local rural hinterland inhabitants, who were constantly under the burden of poverty, hunger, and other war-related effects. Therefore, similar diseases were recorded under symptomatic names such as shaking sicknesses, febbre terziane, and quartane or rheumatic fevers (Anonim, Bilježnica iz farmakologije s početka 19. stoljeća, ZKZ, 163922 Ms 1083: 31a i 32, 52; Muljačić, 1996, 74). nje „zdravih brđana”, Morlaka, koji su bili preseljeni iz brdovitoga sjeverozapadnog područja Bukovice ili čak iz osmanskoga graničnog područja (serbata) (Traljić, 1965, 210-212; Mayhew, 2008, 36-37; Rimac i Mladineo, 2009, 19). Puni predmoderni (i)migracijski potencijal novoga obradivog prostora vidljiv je upravo u privlačenju vlaških stočara iz zaleđa kao snažnih i zdravih "divljaka” ili ,gorštaka” sa sjevera, za koje se očekivalo da će biti otporni i manje podložni endemičnim proto-malaričnim groznicama i drugim bolestima vodenoga okruženja (Peričić, 1971, 405). Osim toga, ti novodoseljeni Morlaci nisu razvili intenzivan otpor prema močvarama kao što je to bila prilika s urbanim elitama (Squatriti, 1992, 5; Mlinarić, 2006, 43-46). Bolesti slične malariji ${ }^{33}$ su u to vrijeme prilično narušavale ekonomsku produktivnost i demografski potencijal stanovništva nizinskih područja. Stoga su Morlake kontinuirano dovodili na posjed $\mathrm{i}$ angažirali na projektima isušivanja i melioracije (Rimac i Mladineo, 2009, 4). Novodoseljenici su ipak primarno angažirani kao radna snaga na napuštenim selištima posjeda. Među njima je bio manji broj koloniziranih seljaka iz sjeverne Italije (Furlanije), ali i znatan broj rodbine postojećih stanovnika, koji su došli u Vranu iz zadarskoga arhipelaga ili širega zaleđa u potrazi za boljom perspektivom ili kao bračni supružnici. Druga vrsta doseljenika, većinom Morlaci, bili su sudionici sezonskih (cirkularnih) stočarskih (transhumantnih) kretanja na području Ravnih kotara (Mlinarić i Župarić-Iljić, 2017, 44-48). S druge su strane dosadašnja istraživanja potvrdila da je mletački interes za stabilizaciju granice pogodovao stimuliranju procesa sedentarizacije doseljenika kao i intenzifikaciji poljoprivredne proizvodnje, što je vodilo oblikovanju specifičnoga kulturnog okoliša (Fuerst-Bjeliš i Zupanc, 2007, 49). Stalna kolonizacija Morlaka u selima vranskoga posjeda, premda brojčano snažna, nije bila potpuno uspješna, dijelom i zbog močvarnih groznica nepoznata uzroka koje su predstavljale zdravstvenu prijetnju. Budući

\footnotetext{
$33 \mathrm{U}$ vrijeme prije znanstvene dijagnostike malarije miješaju se bolest vezane uz određeni medij, npr. vodu. Tako donekle nalikuju simptomi dizenterije i malarije pa čak i dijareje, a općoj malaksalosti organizma stanovnika u dalmatinskom zaleđu ne pomaže ni dugotrajna neimaština te glad kao posljedica ratnih razaranja. Stoga su takve bolesti u izvorima bilježene pod imenima za simptome bolesti koje se vežu uz malariju, primjerice drhtavice, febbre terziane ili quartane odnosno ritmične groznice (Anonim, Bilježnica iz farmakologije s početka 19. stoljeća, ZKZ, 163922 Ms 1083: 31a i 32, 52; Muljačić, 1996, 74).
} 
prior to the late $19^{\text {th }}$ century, popular healing or prevention practices on the Estate were probably scarce and incomplete. Consequently, life near malarial marshes became even more complex, with considerable medical, social, and economic consequences. This engagement on eradication drainage projects was an additional task to the pre-existing role of local inhabitants in the defence system organisation of the Venetian Dalmatian Hinterland (cernide), as a preventive shield to potential Ottoman attacks. Accordingly, their successful integration would seem to be evidence of the effectiveness of the administrative and political organisation of Venetian Dalmatia, which was not actually the case (Mayhew, 2008, 141). Even immigration data enabled researchers to unfold the unstable nature of Morlach settlement; proving that continuous change of labourers in deserted villages was the most prominent early modern demographic characteristic of the area $^{34}$. In such circumstances, the extension of irrigated arable agricultural fields did not prove to be a crucial prerequisite for significant demographic or economic improvement of local villages.

\section{Concluding remarks on methodology challenges in analysis of the melioration results}

This overview of an economically enhanced early modern private environmental project, i.e. the marshland drainage of the Vrana Estate, was made to be evaluated using a computer program to analyse maps as visualisations of demographic-economic statistical data, while the direct correlation of reclamation processes and population growth was another line of research. On the methodological level, certain obstacles or limitations of quantitative analysis with modern analytic tools of the old largescale maps' turned out to be inappropriate for further quantitative geographical information manipulation due to the inconsistencies encountered. Similarly, numerical statistics of various origins were very rare and non-systematic (partial), due to their nature and the principles of data collection, recording,

34 For more on proto-modern migrations, including ecological motives, see Mlinarić and Župarić-Iljić (2017). da je malarija ostala medicinski nedijagnosticirana i znanstveno nepoznata sve do kraja 19. stoljeća, pučke metode liječenja ili prevencije na feudu bile su vjerojatno oskudne i nepotpune. Kao posljedica toga, život u blizini zaraženih močvara postao je za ugrožene ljude još složeniji, uz znatne medicinske, socijalne i ekonomske posljedice. Njihov angažman na projektima isušivanja i odvodnjavanja bio je dodatni teret postojećemu vojničkom izazovu sudjelovanja u obrambenom sustavu mletačkoga zaleđa (sustav cernide), gdje su Morlaci bili dio preventivnoga štita od eventualnih osmanskih upada. Pa iako je administracija mletačke Dalmacije pravdala djelotvornost vlastite birokratske i političke organizacije i njezinu korist za samu Dalmaciju, što je dokazivala i uspješnom integracijom Morlaka, proizlazi da za to nije bilo argumenata (Mayhew, 2008, 141). Čak su i imigracijski podatci potvrđivali nestabilnost pri naseljavanju Morlaka, dokazujući da je kontinuirana promjena obrađivača i korisnika u napuštenim selima bilo najistaknutije ranonovovjekovno demografsko obilježje toga područja. ${ }^{34} \mathrm{U}$ takvim se okolnostima proširenje navodnjavanih poljoprivrednih polja nije pokazalo ključnom pretpostavkom značajnijega demografskog ili ekonomskog razvoja lokalnih sela.

\section{Zaključna razmatranja metodoloških izazova u analizi rezultata melioracije}

U radu je propitana mogućnost korištenja računalnih programa u analizi karte kao prostorne vizualizacije demografskih i ekonomskih statističkih podataka vezanih uz isušivanje močvara na vranskom feudalnom dobru. Stoga su u kratkom pregledu predstavljene okolnosti toga ranonovovjekovnog ekološkog i ekonomskog privatno financiranog projekta. Dodatni smjer istraživanja fokusirao se na mogućnost direktne usporedbe melioracijskih procesa i demografskoga rasta. U metodološkom su smislu uočene određene zapreke odnosno ograničenja kvantitativne analize na temelju obrade starih karata srednjih mjerila suvremenim istraživačkim alatima, čime su se izabrane karte pokazale neadekvatnima za daljnju obradu kvantitativnih podataka. Slično tomu, brojčane se podatke u različitim

34 Više o protomodernim migracijama, uključujući i ekološke obrasce vidi u: Mlinarić i Zuparić-Iljić (2017).
D. Mlinarić I. Kljajić

Early modern

Dalmatian

landscape and

demographic

changes in the

multiple borderland

area: cartographic

vs. statistical data

Ranonovovjekovne okolišne i

demografske

promjene na

dalmatinskom

višestrukom pograničju: usporedba

kartografskih i

statističkih podataka 
GEOGRAFSKI

GLASNIK

82/1,35-58 (2020.) and protection. This makes them hard to compare with other sources, even within the same genre or media of provenance. Furthermore, the problem of early modern source acquisition, translation, or even transliteration into modern code of certain map or statistics, led to speculative source interpretation ambiguities. Since the quantitative analysis and corresponding sources failed to offer a reasonable historical flow or an explanation of land use changes as a potential basis for sustainable ecological, economic, and demographic development, the authors turned to qualitative analysis. Sources showed that the interests of the state powers that ruled Croatian lands, as well as regulations and codes of certain media, considerably determined the resulting variations and inconsistencies in correlated documents. Finally, the importance of marshlands, open fields, and rural areas in the early modern, war-afflicted borderlands were differently perceived and underestimated in relation to, for instance, highly important military facilities. Mud flats were less important quality holders or development accelerators and, consequently, marshland related archival data were not recorded with the same passion as data regarding fortifications. Moreover, the lowland depopulated area of Vrana was therefore perceived as unnecessary, despite its economic potential. However, an innovative cross-media comparison of sources like maps and censuses offers not just a quick insight into the wider picture of environmental changes in borderland areas like Vrana, but also contributed to better knowledge of landscape change in Ravni Kotari in general, and improved the understanding of recent developments in the region.

Regarding the hypothesis on direct correlation of drainage and reclamation processes, with agricultural, as economic, and corresponding demographic improvements, the findings revealed that a strictly determined and defined link was unable to be established due to the absence of a linear set of comparative data. It is usually challenging to directly trace a strict line in a preconditionconsequence process for any of the early modern phenomena without contextual doubts regarding the multiple modifiers. The same was observed when detecting the impact of reclamation and soil improvement projects on fragile landscapes izvorima rijetko može naći i pritom su djelomični i nesustavno prikupljani, dijelom i zbog prirode ili metoda prikupljanja, bilježenja i čuvanja. Stoga se teško mogu uspoređivati ne samo s drugim izvorima, nego čak i unutar istoga žanra odnosno medija kojem pripadaju. Problem nije samo utvrđivanje, prevođenje ili tumačenje starih izvora te prijenos podataka u računalni program, već i njihova spekulativna priroda odnosno mogućnost višestrukoga tumačenja. S obzirom na to da su kvantitativni izvori i analiza podbacili u stvaranju logičnoga tumačenja promjena u korištenju zemlje kao potencijala za stvaranje održivoga ekološkog, ekonomskog i demografskog razvitka, u radu se fokusiralo na kvalitativnu analizu. Izvori su potvrdili znatan utjecaj interesa jakih država koje su vladale hrvatskim prostorom na oblikovanje i nepodudarnosti uspoređenih dokumenata. Konačno, važno je opaziti da su močvare, polja i ruralni prostori na ranonovovjekovnom ratom degradiranom pograničju bili zapostavljeni i drugačije tretirani od, primjerice, izuzetno važnih vojnih objekata. Močvarna tla nisu smatrana važnima ni kao ekonomski potencijal odnosno pokretač razvoja pa se ni građi o njima nije posvećivala jednaka pozornost kao utvrdama te je usprkos svomu ekonomskom potencijalu vranska opustošena nizina bila nebitna. Stoga je ovakvo inovativno transmedijalno uspoređivanje karata i statističkih popisa pružilo uvid i u širu sliku djelovanja okolišnih promjena na pogranična društva poput vranskoga, ali je doprinijelo boljemu ukupnom poznavanju krajobraznih promjena u Ravnim kotarima, pa čak i boljem shvaćanju nedavnih zbivanja na tim prostorima.

Hipoteza o mogućnosti uspostave izravne korelacije procesa isušivanja i melioracije $\mathrm{s}$ poljoprivrednim odnosno ekonomskim i posljedično demografskim napretkom naišla je na prepreku upravo u korištenim izvorima. Zbog parcijalnosti dokumentacije odnosno necjelovitoga i nelinearnoga fonda usporednih podataka jasnu i čvrstu vezu između melioracije i napretka nije bilo moguće uspostaviti. Pronalaženje neposredne veze između određenoga uzroka i posljedice za bilo koji ranonovovjekovni fenomen popriličan je izazov zbog višestrukih čimbenika i modifikatora tih procesa pa je tako bilo i s određivanjem utjecaja projekata melioracije i bonifikacije na promjenu krhkoga oko- 
and rural everyday life in Vrana. Only the broader qualitative analysis captured the importance of marshy borderlands as economically, culturally, but also medicinally-specific lowland areas. It proved the value Vrana's geo-strategic position on the frontier, including the collision of interests of neighbouring imperial powers that directly involved Republic of Venice, the Ottoman Empire, and (in the Hinterland) the Habsburg Monarchy. Demographic increase, which moderately followed irrigation actions was gradual and still endangered by disease epidemics, which had a negative impact on demographics and quality of life. Human intervention in drainage of watery areas (streams, mud flats, and marshes) anthropogenically changed the area. These expensive reclamation actions had not been properly exploited as the nearby Ottoman presence and general insecurity prevented Morlach herders from changing their low-profit herding economy to potentially high-profit crop cultivation. Herding was a propulsive but also pragmatic sort of economic practice, as herds were easy to relocate in the event of raiding. Consequently, new and intensive agricultural exploitation did not take root and enhance the economy, as the prevailing pastoral semi-nomadic herding practices on highly fertile land represented a waste of material and human resources. Furthermore, unfavourable life circumstances in the borderlands, enhanced by overall poverty, became more demanding for inhabitants because the new landscape was dependent on continuous cultivation. It was evident that the processes of water regulation and melioration took place after Vrana lost the characteristics of a borderland region, when the Venetian-Ottoman borderline stabilised further into the Hinterland. While the imbalance in terms of economic interests and environmental exploitation does not speak in favour of the financial sustainability of Borelli's efforts or validate the high expenses, it did add a perspective dimension of cultural values in the evaluation of economic utilisation in retaining the economy-environment relationship at a sustainable level. Even the initial short-term results of the eradication project were a fiasco, shown by the high mortality rate among drainage workers and the financial decadence of liša i svakodnevice ljudi na Vrani. Tek je šira kvalitativna analiza razotkrila važnost vlažnoga pograničja kao ekonomski, kulturno, ali i medicinski specifična nizinskog ambijenta. Tijekom analize valoriziran je geostrateški položaj Vrane na imperijalnim rubovima, na kojima su se prelamali interesi susjednih sila poput izravno uključene Mletačke Republike i Osmanskoga Carstva, ali djelomično čak i Habsburške Monarhije u dubljoj unutrašnjosti. Demografski rast postupno je pratio melioracijske procese premda ga je još uvijek ugrožavala opasnost od močvarnih groznica. One su, naime, smanjivale broj postojećih stanovnika, ali i narušavale kvalitetu života i ekonomsku produktivnost preživjelih. Ljudska intervencija u isušivanje zapuštenih vodnih objekata (potočića, blata i močvara) omogućila je formiranje ambijenta koji je bio stvoren upravo po mjeri čovjeka. Ti skupi i iscrpljujući projekti nisu bili ni potpuno ni odgovarajuće iskorišteni. Naime, osmansko je zadržavanje u okolici i sveukupna nesigurnost spriječila, pa čak i odvratila stočarske Morlake od mijenjanja niskoprofitnoga gospodarenja (stočarenja) za potencijalno profitabilnije mada slabo rašireno intenzivnije ratarsko gospodarstvo i povrtlarstvo. Držanje stoke bila je mnogo propulzivnija i pragmatičnija grana gospodarstva već i stoga što se stoku moglo u slučaju neprijateljskih napada lagano i brzo izmjestiti. Novi i intenzivni načini proizvodne eksploatacije podbacili su jer je zadržavanje pastoralnoga polunomadskog stočarenja na vrlo plodnoj zemlji predstavljalo rasipanje materijalnih i ljudskih resursa te krajnje neracionalno ulaganje energije. Osim toga su nepovoljne životne prilike na granici, potpomognute velikim siromaštvom stavljale sve veće zahtjeve pred stanovništvo jer je novouređeni okoliš tražio kontinuirani ljudski rad na održavanju postojećega stanja. Premda je hidromelioracija nastupila nakon što je Vrana izgubila obilježja pograničnoga prostora, a mletačko-osmanlijska granica stabilizirala se u unutrašnjosti, neravnoteža ekonomskih interesa i korištenja prirodnoga okoliša kao resursa nije uspjela opravdati velike troškove obitelji Borelli te im nije išla u prilog. S druge je strane, iz perspektive promatranja hidromelioracije kao kulturne vrijednosti, ekološko vrednovanje ekonomske eksploatacije usmjerilo razvoj Vrane u pozitivnom smjeru za održivo gospodarenje. No čak su kratkoročni rezultati melioracije bili neuspješni jer je radove inicijalno pratila povećana smrtnost radnika na isušivanju. Posljedično je projekt
Early modern

Dalmatian

landscape and

demographic

changes in the

multiple borderland

area: cartographic vs. statistical data

Ranonovovjekovne okolišne i

demografske

promjene na

dalmatinskom

višestrukom pograničju: usporedba

kartografskih i

statističkih podataka 
GLASNIK

82/1,35-58 (2020.)
Count Borelli himself. In spite of the fact that immigrant Morlachs had not been primarily colonised for reclamation projects, rather as defence troops, colonisation had an ecological character as the new settlers consequently managed to change and reshape the ecologically unstable space of Ravni Kotari in the long term. Despite initial losses, the reclamation results seemed to form the basis for long-term economic improvements over $19^{\text {th }}$ and $20^{\text {th }}$ centuries, with deferred population growth turning this rather adventurous experiment into an economic and demographic success. The land improvement gradually offered new economic possibilities, while improved soil and drained lands allowed slow annual increases in crop yields, improving the food supply of the local population. Based on the creation of more arable land, living standards finally started to increase.

It can be concluded that Vrana Estate's melioration and soil improvement and its impact on ecological, economic, and demographic development of the Zadar hinterland in the turbulent early modern era, can be much more effectively observed qualitatively, rather than quantitatively. This research also shows that the Vrana reclamation project contributed to the realisation of at least some of the demographic potential of the area. By acquiring an extensive area of new, safe fertile land, the local population was able to permanently settle in lowland Vrana villages in larger numbers, improving demographic trends that would further strengthen during the $20^{\text {th }}$ century. doveo i do financijskoga slabljenja grofa Francesca Borellija. Iako doseljeni Morlaci nisu prvotno bili dovedeni zbog samih melioracijskih radova, već kao pomoćne obrambene jedinice, njihovo je dovođenje imalo ekološki karakter jer su kao novi naseljenici u dugoročnoj perspektivi uspjeli promijeniti i preoblikovati ekološki nestabilan prostor Kotara. Usprkos početnim gubitcima, posljedice melioracija predstavljale su temelj dugoročnom ekonomskom oporavku i rastu tijekom 19. i 20. stoljeća. Odgođeni populacijski rast potvrdio je da je avanturistički eksperiment grofa Borellija u konačnici polučio ekonomski i demografski uspjeh. Postupno podizanje kvalitete tla otvaralo je nove ekonomske mogućnosti, dok su bonifikacija tla $\mathrm{i}$ isušivanje omogućavali postupan rast uroda i osiguravali veću samodostatnost lokalnomu stanovništvu. Životni je standard također počeo rasti kako se opseg plodnoga tla širio. Intenzivna poljoprivredna proizvodnja u konačnici je omogućila veće zalihe hrane.

Može se zaključiti da je melioraciju i bonifikaciju tla na vranskom posjedu te njihov utjecaj na ekološki, ekonomski i demografski razvitak zadarskoga nizinskoga zaleđa kao turbulentnoga ranonovovjekovnoga prostora puno jednostavnije temeljito i čvrsto dokazati kvalitativnom nego kvantitativnom analizom. Također je potvrđeno da je projekt melioracije uspio mobilizirati barem dio demografskoga potencijala prostora. Stjecanjem širega prostora vrlo plodne zemlje, zdrave u medicinskom pogledu, lokalno je stanovništvo dobilo pretpostavku za trajno naseljavanje nizinskih sela oko Vrane u većoj mjeri, čime je poboljšalo pozitivne demografske trendove, što se u pravoj mjeri ostvarilo tek u 20. stoljeću.

\section{Literature} Literatura
Blaće, A., 2019: Promjene šumskoga pokrova na području Ravnih kotara u drugoj polovici 19. stoljeća, Hrvatski geografski glasnik 81 (2), 69-88.

Božić-Bužančić, D., 1995: Južna Hrvatska u europskom fiziokratskom pokretu. Pokret za obnowu gospodarstva, gospodarske Akademije, ogledni vrtovi i poljodjelske škole druge polovice XVIII. stoljeća i početka XIX. stoljeća, Književni krug, Povijesni arhiv u Splitu, Zavod za hrvatsku povijest Filozofskog fakulteta Sveučilišta u Zagrebu, Split, Zagreb.

Čuka, A., Graovac Matassi, V., Lončar, N., 2012: Historijsko-geografske promjene u društveno-gospodarskom vrjednovanju ruralnih prostora Ravnih kotara Primjer nadinskog područja (Hrvatska), Annales, Series Historia et Sociologia 22 (1), 157-170.

Faričić, J., 2018: Pakoštane u svjetlu kartografskih izvora: položaj i značenje maloga hrvatskog naselja u velikom sustavu Sredozemlja i Jadrana, in: Radić Rossi, I., Boetto, G. (eds): Pakoštane - Veli Školj: Kasnoantički brodolom u geološko-geografskom i kulturno-povijesnom kontekstu, Sveučilište u Zadru, Institut za pomorsku baštinu Ars Nautica, $\mathrm{Za}$ dar, 135-159.
Fuerst-Bjeliš B., 2003: Reading the Venetian Cadastral Record: An Evidence For the Environment, Population and Cultural Landscape of the 18th Century Dalmatia, Hrvatski geografski glasnik 65 (1), 47-62.

Fürst-Bjeliš, B., D’Alessio, G., Diklić, O., 2003: Mletački katastar i eko-historijska evaluacija Tromeđe, in: Roksandić, D., Mimica, I., Štefanec, N., GlunčićBužančić, V. (eds): Triplex Confinium (1500-1800): Ekohistorija, Književni krug, Zavod za hrvatsku povijest Filozofskog fakulteta Sveučilišta u $\mathrm{Za}^{-}$ grebu, Split, Zagreb, 87-99. 
Fuerst-Bjeliš, B., Lozić, S., Cvitanović, M., Durbešić, A., 2011: Promjene okoliša središnjeg dijela Dalmatinske zagore od 18. stoljeća, in: Matas, M., Faričić, J. (eds): Zagora između stoćarsko-ratarske tradicije te procesa litoralizacije i globalizacije, Sveučilište u Zadru, Kulturni sabor Zagore, Ogranak Matice hrvatske Split, Zadar, 117-130.

Fuerst-Bjeliš, B., Zupanc, I., 2007: New 18th Century Venetian Border in Croatia and its Spatial and Demographic Implications, Hrvatski geografski glasnik 69 (2), 41-52.

Geoportal DGU / Geoportal SGA, Topografska karta 1:25 000 / Topographic map 1:25 000, n. d., https://geoportal.dgu.hr (11.7.2019.)

Hafizović, F., 2016: Popis sela $i$ zemlje sandžaka Krka, Klis i Hercegovina, oslobodenih od Mletačke Republike 1701. godine, SDK Prosvjeta, Filozofski fakultet Sveučilišta u Zagrebu, Orijentalni institut u Sarajevu, Zagreb, Sarajevo.

Mayhew, T., 2008: Dalmatia between Ottoman and Venetian Rule: Contado Di Zara 1645-1718, Libreria Editrice Viella, Rim.

McNeill, J. R., 2003: Observations of the Nature and Culture of Environmental History, Hystory and Theory 42 (4), 5-43.
Mlinarić, D., 2006: Uloga države u prevenciji i sanaciji lošeg utjecaja bolesti na gospodarstvo sjeverne Dalmacije u 18. stoljeću, Ekonomska i ekohistorija: Časopis za gospodarsku povijest i povijest okoliša 2 (2), 39-54.

Mlinarić, D., Miletić Drder, M., 2017: Zbirka Novak: Mappae Croaticae u Zbirci zemljovida i atlasa NSK, Nacionalna i sveučilišna knjižnica u Zagrebu, Zagreb.

Mlinarić, D., Župarić-Iljić, D., 2017: Ranonovovjekovna melioracija, protomoderne migracije i ekonomski razvitak vranskog posjeda, Migracijske i etnicke teme (33) 1, 37-63, DOI: 10.11567/ met.33.1.2.

Muljačić, Ž., 1996: Putovanje Alberta Fortisa po Hrvatskoj i Sloveniji (1765-1791), Književni krug, Split.

Peričić, Š., 1971: Vranski feud i obitelj Borelli, Radovi Instituta JAZU u Zadru 18, 389-411.

Petrić, H., 2012: Pogranična drusttva i okoliš, Meridijani, Društvo za hrvatsku ekonomsku povijest i ekohistoriju, Samobor, Zagreb.

Racz,L., 2010: The price of survival: Transformations in Environmental conditions and subsistence systems in Hungary in the age of Ottoman Occupation, Hungarian studies 24 (1), 21-39.
Rimac, M., Mladineo, G., 2009: Zadarsko okružje na mletačkom katastru iz 1709. godine. Prvi dio: Donji kotar, Državni arhiv u Zadru, Zadar.

Roksandić, D., 2018: Čovjek i prostor, čovjek u okolišu, Meridijani, Društvo za hrvatsku povjesnicu, Centar za komparativnohistorijske $\mathrm{i}$ interkulturne studije Filozofskog fakulteta Sveučilištu u $\mathrm{Za}$ grebu, Samobor, Zagreb.

Slukan Altić, M., 2003: Povijesna kartografija: kartografski izvori u povijesnim znanostima, Meridijani, Samobor.

Squatriti, P., 1992: Marshes and Mentalities in Early Modern Ravenna, Viator 23, 1-16.

Stanojević, G., 2004: Priručnik o vojnim krajinama u Dalmaciji iz 1783, in: Roksandić, D. (ed.): Etnos, konfesija, tolerancija, Prosvjeta, Zagreb, 158-186.

Traljić, S. M., 1965: Zadar i turska pozadina od XV do potkraj XIX stoljeća, Radovi Instituta JAZU u Zadru 21-22, 203-227.

Zahirović, N., 2017:Tragom jedne karijere: Halil-beg (Halil-paša) Memibegović od Like preko Jegra do Banje Luke, Historijski zbornik 70 (2), 353-364.

\section{National and University Library in Zagreb (Nacionalna i sveučilišna knjižnica u Zagrebu (NSK))}

Coronelli, V. M., 1688: Contado di Zara:parte della Dalmatia, NSK, S-JZ-XVII-62, https://digitalna.nsk.hr/pb/?object=info\&id=11276 (11.7.2019.)

Janssonius, I., 1620: Iadera sicum et Aenona vulgo Zara, Sebenico et Nona cum insulis adjacentibus in parte Dalmatiae boreali, NSK, ZN-ZXVII-JAN-1620b, https://digitalna.nsk.hr/pb/?object=info\&id=10252 (11. 7. 2019.)

Melchiori, F., Zavoreo, F. and Furlanetto, L., 1787: Nuova carta topografica della provincia di Dalmazia: divisa ne suoi territorii, NSK, S-JZ-XVIII-22, https://digitalna.nsk.hr/pb/?object=view.dz\&id=11301 (11. 7. 2019.)

Santini, P., 1780: Nouvelle carte de la partie occidentale de Dalmatie, NSK, S-JZ-XVIII-18, https://digitalna.nsk.hr/pb/?object=view. $\mathrm{dz \&}$ id $=11298$ (11. 7.2019.)

State Arhives in Zadar (Državni arhiv u Zadru (DAZD))

HR-DAZD-348, Obitelj Borelli-Galbiani-Vranski feud, Zadar (1439.-1934.), Anonim, s.d.: Dissegno della Palude di Wrana, Rukopisni crtež vranskih močvara, svežanj 2 , svežnjić $\mathrm{C}$, br. 8 .

HR-DAZD-348, Anonim, s.d.: Dissegno della Palude di Wrana, Rukopisni crtež vranskih močvara, svežanj 2, svežnjić C, br. 9.

HR-DAZD-348, Anonim, s.d.: Dissegno della Palude di Wrana, Rukopisni crtež vranskih močvara, svežanj 2, svežnjić C, br. 12.

HR-DAZD-348, Evidencija feudalnog posjeda Borelli, IV (Ekonomija feuda), kut. 97.

HR-DAZD-348, Katastarska karta Vrane, sv. 2, 38, 1 (Vrana).

HR-DAZD-348, Albero Genealogico di Tign,IV, kut. 98, br. 72/1-30.

HR-DAZD-348, Disposizion Sindici Inquisitori in Dalmazia, come dalla Stampa Adu. c. 265. Anime ritrouate da Sindici Adu. c. 265, IV, Ekonomija feuda, sv. 39, IV, br. 27, 292.

\section{Sources}

Izvori
Early modern

Dalmatian

landscape and

demographic

changes in the

multiple borderland

area: cartographic

vs. statistical data

Ranonovovjekovne okolišne i

demografske

promjene na

dalmatinskom

višestrukom pograničju: usporedba

kartografskih i statističkih podataka 
HRVATSKI GEOGRAFSKI GLASNIK $82 / 1,35-58$ (2020.)
HR-DAZD-348, Disposizion Prou. Gen. Grimani, come dalla Stampa Adu. A. c. 266, IV, Ekonomija feuda, sv. 39, br. 27.

HR-DAZD-348, Popis naknade za travarinu (herbatico), 1795, sv. 6, 2.

HR-DAZD-348, Hidrotehnički inženjerski plan, sv. 4, M, 3.

HR-DAZD-348, Hidrotehnički inženjerski plan, sv. 4, M, 5.

HR-DAZD-348, Statistika feudalnog posjeda Borelli 1752.-1798., sv. 60, br. I/IV.

HR-DAZD-383, Kartografska zbirka, Lodoli, G. B., 1756: Pianta o sia dissegno delle pertinenze di Vrana Tign, Bagnevaz, e Radassinovaz, con li colli Cernogora, Modrave, Tatigne et altri ..., br. 2.2.9.

HR-DAZD-6, Mletački katastar, Mape Grimani, zemljovid Zadarskog distrikta 1709., br. 511.

Scientific Library in Zadar (Znanstvena knjižnica u Zadru (ZKZ))

Anonim, Bilježnica iz farmakologije s početka 19. stoljeća, ZKZ, 163922, Ms 1083: 31a i 32, 52.

Feudi in Dalmazia sotto il governo veneto, ZKZ, Ms. 110, 88.
Authors Autori
Dubravka Mlinarić dubravka.mlinaric@imin.hr PhD, Scientific Advisor, Institute for Migration and Ethnic Studies, Trg Stjepana Radića 3, 10000 Zagreb, Croatia

Ivka Kljajić ikljajic@geof.hr $\mathrm{PhD}$, Assistant Professor, University of Zagreb, Faculty of Geodesy, Kačićeva 26, 10000 Zagreb, Croatia 